\title{
New insights on the effects of ionic liquid structural changes at the gene expression level: Molecular mechanisms of toxicity in Daphnia magna
} \author{
Jana Asselman ${ }^{c}$, Joana L. Pereira ${ }^{a, *}$

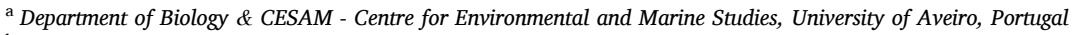 \\ ${ }^{\mathrm{b}}$ Department of Chemistry \& CICECO - Aveiro Institute of Materials, University of Aveiro, Portugal \\ ${ }^{c}$ Blue Growth Research Lab, Ghent University, Bluebridge Building, Ostend Science Park 1, 8400 Ostend, Belgium
}

Guilherme Jeremias $^{\mathrm{a}}$, Fátima Jesus ${ }^{\mathrm{a}}$, Sónia P.M. Ventura ${ }^{\mathrm{b}}$, Fernando J.M. Gonçalves ${ }^{\mathrm{a}}$,

\section{A R T I C L E I N F O}

\section{Editor: Dr. R. Debora}

\section{Keywords:}

Ionic liquids

Alkylimidazolium chloride

Cholinium chloride

Ecotoxicity

Gene expression

\begin{abstract}
A B S T R A C T
Knowledge on the molecular basis of ionic liquids' (ILs) ecotoxicity is critical for the development of these designer solvents as their structure can be engineered to simultaneously meet functionality performance and environmental safety. The molecular effects of ILs were investigated by using RNA-sequencing following Daphnia magna exposure to imidazolium- and cholinium-based ILs: 1-ethyl-3-methylimidazolium chloride $\left(\left[\mathrm{C}_{2} \mathrm{mim}\right] \mathrm{Cl}\right)$, 1-dodecyl-3-methylimidazolium chloride $\left(\left[\mathrm{C}_{12} \mathrm{mim}\right] \mathrm{Cl}\right)$ and cholinium chloride $([\mathrm{Chol}] \mathrm{Cl})$-; the selection allowing to compare different families and cation alkyl chains. ILs shared mechanisms of toxicity focusing e.g. cellular membrane and cytoskeleton, oxidative stress, energy production, protein biosynthesis, DNA damage, disease initiation. $\left[\mathrm{C}_{2} \mathrm{mim}\right] \mathrm{Cl}$ and $\left[\mathrm{C}_{12} \mathrm{mim}\right] \mathrm{Cl}$ were the least and the most toxic ILs at the transcriptional level, denoting the role of the alkyl chain as a driver of ILs toxicity. Also, it was reinforced that [Chol] Cl is not devoid of environmental hazardous potential regardless of its argued biological compatibility. Unique gene expression signatures could also be identified for each IL, enlightening specific mechanisms of toxicity.
\end{abstract}

\section{Introduction}

Ionic liquids (ILs) are a broad group of salts with low melting points that firstly emerged as "green" solvents by being more efficient, effective and environmentally friendly than traditional solvents (Plechkova and Seddon, 2008; Pawłowska et al., 2019). Ionic liquids have been gaining attention because of their design character - they exhibit distinct physical and chemical properties depending upon their chemical structure; thus their design can be tuned for a specific application (Plechkova and Seddon, 2008). Due to nearly unlimited possibilities of IL structures by cation and anion selection and functionalization, their range of application has been broadening from their traditional use as designer solvents in organic reactions to fields as diverse as electronics, polymers, nanomaterials, biomass processing, spectroscopy, optics, lubricants, fuels, and refrigerants (Kubisa, 2004; Plechkova and Seddon, 2008). Such a broad range of applications will likely lead to a massive increase in their industrial use, as supported by the exponential rise in the field's publications and patents (Pawłowska et al., 2019; Shamshina and Rogers, 2020). This widespread use will result in ILs acting as environmental pollutants by originating in industrial post-production waste, discharge of untreated or ineffectively treated wastewater and accidental spills occurring during processing or transportation (Zhao et al., 2007; Amde et al., 2015). As the legislation for commercializing new chemicals is now stringent (e.g. see REACH; EC Regulation no. 1907/2006), the optimization of ILs' technical performance needs to run in parallel with the minimization of negative environmental impacts (Ventura et al., 2013; Amde et al., 2015).

Despite being initially touted as "green" solvents, ILs are not devoid of toxicity and can pose a threat to human health and lead to negative environmental effects to aquatic biota (Romero et al., 2008; Thuy Pham et al., 2010; Cvjetko Bubalo et al., 2014; Santos et al., 2015; Macário et al., 2020). Ionic liquids toxicity depends on their specific structure and molecular architecture, cation and anion cores and physical and chemical properties (Matzke et al., 2013; Cvjetko Bubalo et al., 2014). The increased knowledge regarding the toxicity of ILs lead to the establishment of the so-called heuristic rules of design, i.e. general trends when designing ILs towards better performance regarding toxicity and biodegradability, the most paradigmatic example being that

\footnotetext{
* Correspondence to: Department of Biology \& CESAM, University of Aveiro, 3810-193 Aveiro, Portugal.

E-mail address: jpereira@ua.pt (J.L. Pereira).
} 
longer alkyl chains increase ILs toxicity (Matzke et al., 2013; Cvjetko Bubalo et al., 2014). However, several exceptions to the heuristic rules have been found, with literature presenting contradictory results as well as data gaps concerning the biological effects and mechanistic aspects of ILs toxicity (Santos et al., 2015; Heckenbach et al., 2016; Parajó et al., 2019). Thus, the development of truly environmental friendlier ILs can benefit from clarifying structure-ecotoxicity relationships and unveiling the molecular basis of ILs toxicity (Ventura et al., 2013; Heckenbach et al., 2016; Parajó et al., 2019). Next-generation sequencing technologies have already been employed to address biotechnological exploitation of fungi and bacteria using ILs (Khudyakov et al., 2012; Alves et al., 2016), but RNA-sequencing (high-throughput, high-speed and high-sensitivity technique), enabling the quantification of gene expression across the whole transcriptome, can be used to broadly uncovering of mechanisms of toxic action while contributing to the environmental risk assessment of these compounds (Ozsolak and Milos, 2011; Han et al., 2015).

Imidazolium- and cholinium-based ILs are amongst the most studied and important families of ILs. Imidazolium-based ILs have widespread applications in different industries, e.g. lubricants, solvents for synthesis, separation and purification processes, drug synthesis and drug delivery systems (Egorova et al., 2017; Ventura et al., 2017; Liu et al., 2019), but they can be toxic for human cells and aquatic organisms, with longer alkyl chains typically inducing higher toxic effects (Bernot et al., 2005; Yu et al., 2009; Ventura et al., 2013; Bubalo et al., 2017; Zhang et al., 2017). Cholinium-based ILs show a range of foreseen applications, including their use as solvents for biocatalysis and biomass conversion, biopolymer science, separation and purification processes (Garcia et al., 2010; Egorova et al., 2017; Ventura et al., 2017). Despite the higher "biocompatibility" and biodegradability of cholinium-based ILs that contribute to a supposed lower environmentally hazardous potential compared to imidazolium-based ILs, experimental studies already highlighted the toxic potential of some of these structures (Sintra et al., 2017; Santos et al., 2015; Mena et al., 2020). Although it has been proposed that cholinium-based ILs exhibit different mechanisms of toxicity than imidazolium-based ILs, these mechanisms remain mildly studied (Ventura et al., 2014; Santos et al., 2015; Heckenbach et al., 2016). Yet, molecular studies revealed that the toxicity of ILs relies predominately on cell membrane damage and oxidative stress (Thuy Pham et al., 2010; Costa et al., 2017). In fact, ILs can bind and interact with the cell membrane, possibly leading to cell permeability changes and the affectation of cell integrity that ultimately can result in cell death, as well as promote the entrance of ILs into the cytoplasm, thereby exacerbating negative cellular effects (Hartmann et al., 2015; Galluzzi et al., 2018). Above all, these effects seem to result from oxidative stress, as production of reactive oxygen species (ROS; e.g. $\mathrm{O}_{2} \bullet-, \mathrm{OH} \bullet$, and $\mathrm{H}_{2} \mathrm{O}_{2}$ ) has been reported in different species due to ILs exposure (Kumar et al., 2011; Du et al., 2014). Downstream consequences such as the inefficiency of the antioxidant system in mitigating ROS insult following exposure to ILs has also been shown, including further membrane damage, lipid peroxidation, mitochondria impairment and DNA damage (Cvjetko Bubalo et al., 2014; Du et al., 2014; Costa et al., 2017). Ultimately, ILs-related oxidative stress was already linked to apoptosis, i.e. programmed cell death (Ranke et al., 2006; Li et al., 2012; Martins et al., 2013). Changes in the structure and function of different cell organelles, such as the mitochondria, endoplasmic reticulum and chloroplasts, have also been reported as direct effects of ILs and/or the indirect effect of ROS damage (Liu et al., 2015; Chen et al., 2018; Xia et al., 2018).

Taking the above into account, the general aim of this study was to understand how the design of imidazolium- and cholinium-based ILs can translate into differential mechanisms of toxicity at the molecular level through RNA-sequencing (i.e. covering for most of the theoretically possible mechanisms of toxicity triggered at the transcriptomic level). Daphnia magna was used as a model species. Due to its key role in freshwater food webs decisively supporting the structure and function of freshwater ecosystems (Hall et al., 1976; Carpenter et al., 1985;
Lampert, 2006), and proven sensitivity to a wide range of environmental contaminants, this species was established as a model in different fields, including ecotoxicology and consequently the setting of regulatory standards for environmental protection (Lampert, 2006; Colbourne et al., 2011; Miner et al., 2012). By assessing gene expression patterns following $D$. magna exposure to three judiciously selected ILs - 1-ethyl-3-methylimidazolium chloride $\left(\left[\mathrm{C}_{2} \mathrm{mim}\right] \mathrm{Cl}\right), 1$-dodecyl-3-methylimidazolium chloride $\left(\left[\mathrm{C}_{12} \mathrm{mim}\right] \mathrm{Cl}\right)$ and cholinium chloride $([\mathrm{Chol}] \mathrm{Cl})-$, we specifically aimed at assessing and comparing: (i) the effect of the elongation of the alkyl chain of the cation by confronting $\left[\mathrm{C}_{2} \mathrm{mim}\right] \mathrm{Cl}$ with $\left[\mathrm{C}_{12} \mathrm{mim}\right] \mathrm{Cl}$, which are extremes within the most common representatives of imidazolium-based ILs bearing a similar cation structure and the same anion regarding the alkyl chain length but also, and consequently, expected environmental toxicity in general; (ii) the effects of different cations $\left(\left[\mathrm{C}_{2} \mathrm{mim}\right] \mathrm{Cl}\right.$ vs. $\left.[\mathrm{Chol}] \mathrm{Cl}\right)$ in modulating toxicity mechanisms.

\section{Experimental}

\subsection{Chemicals}

The imidazolium-based ILs used in this experiment, i.e. 1-ethyl-3methylimidazolium chloride $\left(\left[\mathrm{C}_{2} \mathrm{mim}\right] \mathrm{Cl}\right.$; CAS 65039-09-0) and 1dodecyl-3-methylimidazolium chloride $\left(\left[\mathrm{C}_{12} \mathrm{mim}\right] \mathrm{Cl}\right.$; CAS $114569-84-$ 5) were acquired from Iolitec (Germany), bearing $>98 \%$ purity. Cholinium chloride ([Chol]Cl; CAS 67-48-1) was purchased from SigmaAldrich, also bearing $>98 \%$ purity. For the exposures, stock solutions of each IL were prepared in the appropriate $D$. magna culture medium (ASTM hard water (ASTM, 1980)) and test solutions were prepared by direct dilution. Chemicals used to prepare the culture medium were of analytical grade.

\subsection{D. magna culturing and exposure levels establishment}

Monoclonal cultures of Daphnia magna (clone Beak) have been reared in our laboratory for more than 50 generations, in ASTM hard water medium enriched with vitamins and supplemented with an organic additive (Ascophyllum nodosum extract) (Baird et al., 1989), under a temperature of $20 \pm 2{ }^{\circ} \mathrm{C}$ and a $16 \mathrm{~h} / 8 \mathrm{~h} \mathrm{light/dark} \mathrm{photoperiod}$ provided by cool fluorescent white lights. The culture medium is renewed and organisms are fed three times a week with concentrated suspensions of Raphidocelis subcapitata $\left(3 \times 10^{5}\right.$ cells $\left.\mathrm{mL}^{-1}\right)$, which is cyclically cultured in Woods Hole MBL (Stein, 1973). In order to define exposure levels for the definite experiment, standardized acute toxicity tests were run (OECD, 2004). Briefly, D. magna neonates, ageing less than $24 \mathrm{~h}$ and born between the 3rd and 5th brood in the bulk cultures, were exposed to a range of concentrations of each IL and a blank control for $48 \mathrm{~h}$, with no food supply and under the same photoperiod and temperature previously described for cultures. Each treatment was set with 4 replicates holding 5 neonates each. Immobilization was recorded at the end of each test and the effective concentration causing $20 \%$ immobilization $\left(\mathrm{EC}_{20}\right)$ was estimated by Probit Analysis: $352.2 \mathrm{mg} \mathrm{L}^{-1}$ for [Chol] Cl (95\% CI: 239.4-428.5 $\left.\mathrm{mg} \mathrm{L}^{-1}\right)$; $126.3 \mathrm{mg} \mathrm{L}^{-1}$ for [C $\mathrm{C}_{2} \mathrm{mim}$ ] $\mathrm{Cl}$ (95\% CI: $\left.110.1-138.8 \mathrm{mg} \mathrm{L}^{-1}\right) ; 2.270 \times 10^{-3} \mathrm{mg} \mathrm{L}^{-1}$ for $\left[\mathrm{C}_{12} \mathrm{mim}\right] \mathrm{Cl}$ ( $95 \%$ CI: $1.794 \times 10^{-3} \mathrm{mg} \mathrm{L}^{-1}-2.668 \times 10^{-3} \mathrm{mg} \mathrm{L}^{-1}$ ).

\subsection{D. magna experiment for gene expression analysis}

Before starting the experiment, dedicated bulk cultures were established for a synchronized yield of the 3rd brood neonates needed (1440), all strictly ageing less than $10 \mathrm{~h}$ old to avoid age-related interference in gene expression patterns. These neonates were then randomly assigned to 12 glass vessels comprising three replicates for each of the four treatments, i.e. control (blank ASTM medium) and $\mathrm{EC}_{20}$ of [Chol] $\mathrm{Cl}$, $\left[\mathrm{C}_{2} \mathrm{mim}\right] \mathrm{Cl}$ and $\left[\mathrm{C}_{12} \mathrm{mim}\right] \mathrm{Cl}$. Each replicate contained a total of 120 neonates in $500 \mathrm{~mL}$ of test solution, and the exposure lasted for exactly 
$48 \mathrm{~h}$ with no food addition, under the same temperature and photoperiod conditions as previously described for cultures. After exposure, active organisms were randomly collected from each replicate into RNAlater ${ }^{\circledR}$ for further storage at $-80^{\circ} \mathrm{C}$.

\subsection{RNA extraction, library preparation and sequencing}

As appropriate amounts of RNA were not available from single individuals, pools of 90 individuals collected from each replicate were used for extraction; this approach has been followed in several other studies. Organisms were homogenized with a disposable pestle before RNA extraction with the RNeasy kit and Qiashredder by Qiagen (Venlo, Netherlands) following the manufacturer's protocol. After extraction, the quality and concentration of the RNA were assessed by using a NanoDrop 1000 spectrophotometer (NanoDrop Technologies, Wilmington, DE, USA); RNA integrity was assessed in a 1\% agarose TAE gel electrophoresis stained with Green Safe Premium (NZYTech, Portugal) and visualized under UV light. RNA samples passing this preliminary quality check and further quality analysis (RIN $\geq 7$, input of $\geq 1 \mu \mathrm{g}$ total RNA and free of contaminating DNA) were sequenced (STABvida, Portugal). The library construction of cDNA molecules was carried out using the Kapa Stranded mRNA Library Preparation Kit (Kapa Biosystems) and the generated DNA fragments were sequenced in an lllumina HiSeq 4000 platform, using 150 bp paired-end sequencing reads.

\subsection{Bioinformatics and data analysis}

On average, $5.2 \times 10^{7} \pm 7.6 \times 10^{6}$ reads were generated per sample. First, the quality of the reads was analyzed with FastQC (version 0.11.9, Babraham Bioinformatics). Then, reads were trimmed with Trimmomatic (version 0.39) (Bolger et al., 2014) and the success of this task was validated by re-running reads quality analysis in FastQC. Processed sequencing reads were deposited in GEO and are available under the accession number: GSE156769. The cleaned reads were mapped against the reference transcriptome of $D$. magna (Orsini et al., 2016) using the STAR aligner, version 2.7.3a (Dobin et al., 2013). HTseq-count (Anders et al., 2015) in the intersection-nonempty mode (for a full picture on overlapping gene models and thus ambiguity level of each mapping strategy) was used for reads counting.

The dataset was filtered to discard genes with less than $1 \mathrm{cpm}$ in at least two samples. This resulted in 15,115 quantifiable genes, which were normalized to correct for compositional bias among samples, using the trimmed mean of M-values (Robinson and Oshlack, 2010). Exploratory unsupervised clustering analysis of gene expression based on log-fold-change and considering all samples was first run, and summarized in a multi-dimensional scaling (MDS) plot to examine intra-treatment consistency among replicates and to gain an overview of the magnitude of the expectable differences among ILs in gene expression patterns. A GLM approach with specific contrasts (quasi-likelihood, QL, F-test) was used to test for differential gene expression among treatments: (i) control vs. each IL treatment to address its effects; (ii) $\left[\mathrm{C}_{2} \mathrm{mim}\right] \mathrm{Cl}$ vs. [Chol] $\mathrm{Cl}$ to address the effects of the cation; (iii) $\left[\mathrm{C}_{2} \mathrm{~min}\right]$ $\mathrm{Cl}$ vs. $\left[\mathrm{C}_{12} \mathrm{mim}\right] \mathrm{Cl}$ to address the effects of the elongation of the alkyl chain. Accounting for multiple testing errors, significant differences were assigned at a false discovery rate (FDR) of $5 \%$. For each contrast, differentially expressed genes were annotated (Orsini et al., 2016) and KEGG enrichment analysis (Subramanian et al., 2005) followed through the Fisher's exact test to identify significantly over-represented ontologies, gene families and gene pathways.

Unless stated otherwise, data analysis was run in $\mathrm{R}$ version 3.6.1 (Team, 2019), using the EdgeR package (Robinson and Oshlack, 2010).

\section{Results and discussion}

In this study, we exposed D. magna to concentrations found equitoxic at the individual level (immobilization $\mathrm{EC}_{20}$ ). These $\mathrm{EC}_{20}$ estimates (see
$\mathrm{EC}_{20}$ values detailed in Section 2.2) show that, considering an integrative endpoint at the individual level, [Chol] $\mathrm{Cl}$ and $\left[\mathrm{C}_{12} \mathrm{mim}\right] \mathrm{Cl}$ are the least and the most toxic ILs, as well as that $\left[\mathrm{C}_{12} \mathrm{mim}\right] \mathrm{Cl}$ is much more toxic than $\left[\mathrm{C}_{2} \mathrm{mim}\right] \mathrm{Cl}$ at the individual level. Thus, toxicity patterns at the individual level agree with the previously postulated heuristic rules relating structure and ecotoxicity of ILs by confirming the influence of the elongation of the alkyl chain of the imidazolium cation $\left(\left[\mathrm{C}_{2} \mathrm{mim}\right] \mathrm{Cl}\right.$ vs. $\left.\left[\mathrm{C}_{12} \mathrm{mim}\right] \mathrm{Cl}\right)$ as a key driver of toxicity, as well as the higher capacity of the imidazolium cation to cause harm compared to the cholinium cation $\left(\left[\mathrm{C}_{2} \mathrm{mim}\right] \mathrm{Cl}\right.$ vs. [Chol] $\left.\mathrm{Cl}\right)$ (Ventura et al., 2013; Santos et al., 2015).

\subsection{Overall gene expression patterns following exposure to the three tested ILs}

When normalizing the exposure to equitoxic levels among all ILs (exposures run at the concentration expected to elicit 20\% immobilization of D. magna, i.e. $\mathrm{EC}_{20}$, for all tested ILs), our intent was to reach also equitoxic levels at the molecular level, thus very distinctive gene expression magnitudes among ILs were not expected but rather evidences of distinct mechanisms of toxic action. Instead, we observed clear separate clusters for the three ILs at the molecular level, with $\left[\mathrm{C}_{2} \mathrm{mim}\right] \mathrm{Cl}$ spatially associated with the control with low gene expression levels, while $\left[\mathrm{C}_{12} \mathrm{mim}\right] \mathrm{Cl}$ and [Chol] $\mathrm{Cl}$ were clearly teased apart by scaling higher gene expression levels in the first or the second axis, respectively (Fig. 1). This primarily evidences that toxicity ranging depends on the focused endpoint and that toxicity at the individual level, necessarily reflecting the integration of multiple cellular and organismal processes, is not necessarily a direct translation of toxicity at lower levels of biological organization, such as the transcriptional level. On the other hand, it supports the alkyl chain effect at the molecular level as the exposure to $\left[\mathrm{C}_{12} \mathrm{mim}\right] \mathrm{Cl}$ affected gene expression more pronouncedly than exposure to $\left[\mathrm{C}_{2} \mathrm{mim}\right] \mathrm{Cl}$ (Fig. 1 ) even though at the organismal level the exposure was equitoxic for the endpoint immobility. It is well established as a heuristic rule for ILs toxicity that the increase of the cation alkyl chain length provokes higher toxicity ("side-chain" effect) for a wide variety of endpoints (e.g. survival, reproduction, behavior) in different species and in D. magna responding to imidazolium-based ILs in particular (Bernot et al., 2005; Yu et al., 2009; Ventura et al., 2013; Bubalo et al., 2017; Zhang et al., 2017). This is because the elongation of the alkyl chain increases the lipophilicity and/or hydrophobicity of ILs, which in turn determines a higher capacity to disrupt the cell membrane and its permeability (Mendonca et al., 2018), eventually allowing IL accumulation in the cytoplasm and consequently promoting intracellular mechanisms of toxicity (Ranke et al., 2006; Li et al., 2012; Cook

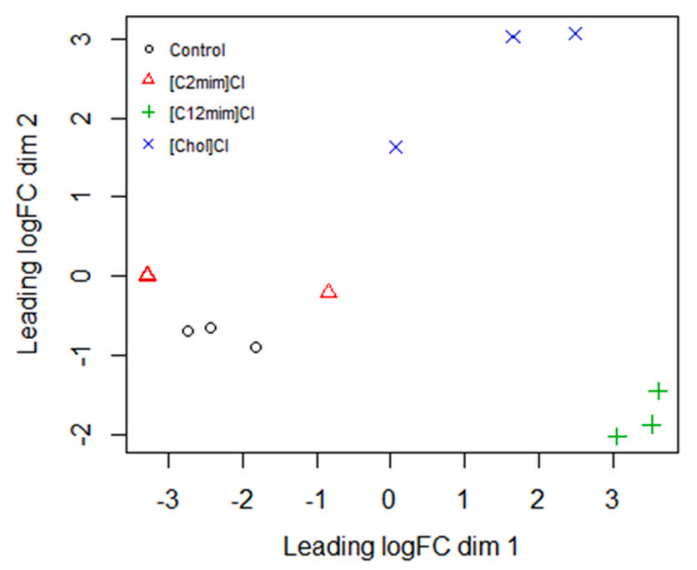

Fig. 1. Summary (two-dimensional MDS plot) of the similarity analysis among all RNA replicated samples obtained following exposure of D. magna to [Chol] $\mathrm{Cl},\left[\mathrm{C}_{2} \mathrm{mim}\right] \mathrm{Cl},\left[\mathrm{C}_{12} \mathrm{mim}\right] \mathrm{Cl}$ and a blank control, based on normalized gene expression levels (log-fold-change, $\log \mathrm{FC}$ ). 
et al., 2019). The marked difference between the expression profiles of the control and $\left[\mathrm{C}_{12} \mathrm{mim}\right] \mathrm{Cl}$ was expected as it is in line with the high toxic potential of this IL to Daphnia (Wells and Coombe, 2006) and with what was concomitantly observed herein, i.e. by lowest $\mathrm{EC}_{20}$ concentration by several orders of magnitude among the three ILs (see Section 2.2).

On the other hand, and although generally in line with the heuristic rule defining that the cation has a prominent role in defining ILs toxicity, the higher relative impact found at the molecular level of [Chol]Cl compared to $\left[\mathrm{C}_{2} \mathrm{mim}\right] \mathrm{Cl}$ was somewhat unexpected, given that $[\mathrm{Chol}] \mathrm{Cl}$ exhibited the lowest toxicity at the individual level, with an $\mathrm{EC}_{20}$ estimate three times higher than that of $\left[\mathrm{C}_{2} \mathrm{mim}\right] \mathrm{Cl}$ (see Section 2.2). It has been noticed that not all cholinium-based ILs are devoid of environmental hazardous potential although these ILs have been typically touted as safer than ILs belonging to other families, and [Chol] $\mathrm{Cl}$ is amongst the least toxic ILs of the cholinium family (Ventura et al., 2014; Santos et al., 2015; Sintra et al., 2017). Its lower toxicity compared to $\left[\mathrm{C}_{2} \mathrm{mim}\right] \mathrm{Cl}$ has been evidenced, for example (i) for $D$. magna, by a three-fold higher 48-h immobilization $\mathrm{EC}_{20}$ (present study; Section 2.2); (ii) concerning the bioluminescence of Aliivibrio fischeri (Munoz et al., 2015) and (iii) regarding antimicrobial activity (Petkovic et al., 2009; Santos et al., 2014). Remarkably, as far as we could identify in the literature, the comparison between these two ILs regarding ecotoxicity is limited to acute/short-term exposures. It is reasonable to hypothesize that mechanisms of toxicity identified at the transcriptional level following exposure to both ILs translate into effects at the individual level at different paces. Because gene expression patterns have been recognized as early-warning biomarkers of exposure (Piña et al., 2007), our profile for [Chol]Cl may highlight mechanisms of toxicity (see below) that would only be pictured at the individual level following chronic exposure test protocols, potentially repositioning [Chol] $\mathrm{Cl}$ and $\left[\mathrm{C}_{2} \mathrm{mim}\right] \mathrm{Cl}$ as to their relative toxicity. Regardless of this hypothesized revolution in the current understanding of the environmental safety of the cholinium cation compared to imidazolium counterparts, the distinctive gene expression patterns of $[\mathrm{Chol}] \mathrm{Cl}$ and $\left[\mathrm{C}_{2} \mathrm{mim}\right] \mathrm{Cl}$ obtained herein clearly support previous claims that cholinium-based ILs exhibit different mechanisms of toxicity than imidazolium-based ILs (Ventura et al., 2014; Sharma and Mukhopadhyay, 2018).

Consistently with the general patterns regarding expression levels above, quantitative analysis of differentially expressed genes relative to the control reveals a dramatic increase in numbers when comparing exposure to $\left[\mathrm{C}_{2} \mathrm{mim}\right] \mathrm{Cl}$ with exposure to $\left[\mathrm{C}_{12} \mathrm{mim}\right] \mathrm{Cl}$ and $[\mathrm{Chol}] \mathrm{Cl}$ treatments (Table 1 ). This supports that $\left[\mathrm{C}_{2} \mathrm{mim}\right] \mathrm{Cl}$ bears the lowest potential to induce transcriptional changes in D. magna, apparently

\section{Table 1}

Overview of the differential gene expression resulting from exposure of $D$. magna to selected ILs $\left(\left[\mathrm{C}_{2} \mathrm{mim}\right] \mathrm{Cl},\left[\mathrm{C}_{12} \mathrm{mim}\right] \mathrm{Cl}\right.$ and $\left.[\mathrm{Chol}] \mathrm{Cl}\right)$ compared to the control; the last two columns provide the corresponding view on specific contrasts made to address the postulated heuristic rules for IL toxicity. Detailed in the table is the number of significantly differentially expressed genes within each contrast (GLM; FDR level of 0.05 ) or the number of over-represented gene ontologies, gene families and gene pathways (Fisher's exact test; $\mathrm{p}<0.01$ ).

\begin{tabular}{|c|c|c|c|c|c|}
\hline & $\begin{array}{l}{\left[\mathrm{C}_{2} \mathrm{mim}\right]} \\
\mathrm{Cl}\end{array}$ & $\begin{array}{l}{\left[\mathrm{C}_{12} \mathrm{mim}\right]} \\
\mathrm{Cl}\end{array}$ & $\begin{array}{l}{[\mathrm{Chol}]} \\
\mathrm{Cl}\end{array}$ & $\begin{array}{l}{\left[\mathrm{C}_{2} \mathrm{mim}\right] \mathrm{Cl}} \\
\text { vs. }[\mathrm{Chol}] \mathrm{Cl}\end{array}$ & $\begin{array}{l}{\left[\mathrm{C}_{2} \mathrm{mim}\right] \mathrm{Cl}} \\
\text { vs. }\left[\mathrm{C}_{12} \mathrm{mim}\right] \\
\mathrm{Cl}\end{array}$ \\
\hline Genes & 257 & 5598 & 6216 & 4681 & 7073 \\
\hline $\begin{array}{l}\text { Up- } \\
\text { regulated }\end{array}$ & 145 & 2263 & 2768 & & \\
\hline $\begin{array}{l}\text { Down- } \\
\text { regulated }\end{array}$ & 112 & 3335 & 3448 & & \\
\hline $\begin{array}{l}\text { Gene } \\
\text { ontology }\end{array}$ & 10 & 44 & 19 & 25 & 22 \\
\hline $\begin{array}{l}\text { Gene } \\
\text { family }\end{array}$ & 3 & 25 & 12 & 19 & 12 \\
\hline $\begin{array}{l}\text { Gene } \\
\text { pathway }\end{array}$ & 1 & 11 & 3 & 11 & 7 \\
\hline
\end{tabular}

confirming the inconsistency of the picture touting cholinium cations as environmentally safer than imidazolium cations. Nevertheless, it is noteworthy that [Chol] $\mathrm{Cl}$ exposure presented the highest number of genes differentially expressed from the control (Table 1). In agreement, gene ontology, family and pathway significant enrichment trends were most responsive to $\left[\mathrm{C}_{12} \mathrm{mim}\right] \mathrm{Cl}$ (Table 1 ), thus further reinforcing the following relative toxicity ordering at the transcriptional level: $\left[\mathrm{C}_{2} \mathrm{mim}\right]$ $\mathrm{Cl}<[\mathrm{Chol}] \mathrm{Cl} \ll\left[\mathrm{C}_{12} \mathrm{mim}\right] \mathrm{Cl}$.

\subsection{Gene expression patterns shared by the three tested ILs: common routes of toxic action}

In spite of the differences in the gene expression profiles induced by the tested ILs, 242 genes significantly differentially expressed compared to the control were shared by the three of them (Fig. 2), these being the genes likely marking the general molecular mechanisms of ILs toxicity. However, the enrichment analysis revealed that none gene families or metabolic pathways were shared by the three ILs (Fig. 3). Three gene ontologies were shared by the three ILs treatments (Fig. 3) but no significant enrichments occurred at this level, with underrepresentation being rather observed (see Table 2). Based on similar transcriptomic responses observed in the exposure of Daphnia to different stressors (Asselman et al., 2012; De Coninck et al., 2014), as well as on the toxicity mechanisms reported in literature for ILs (see Introduction), we expected effects on genes involved in membrane disruption, ROS handling, mitochondrial metabolism and protein synthesis to be shared by the three ILs. Our results are consistent with this expectation, especially at the differential expression level.

Membrane disruption is the mechanism most commonly reported for ILs toxicity (this is not so straightforward for [Chol]Cl; (Mendonca et al., 2018)), as these compounds typically have the primary capacity of attacking the double-layered lipid structure of the membrane by binding, inserting and disputing it, leading to membrane permeation and damage (Hartmann et al., 2015; Cook et al., 2019). In addition, it has been reported that ILs act as polar narcotics, thus causing membrane-bound protein disruption, which leads to changes in cell functionality and ultimately cell death (Zhao et al., 2007; Yoo et al., 2016; Bubalo et al., 2017). In agreement, we observed major changes in membrane-related genes (Supplementary Table S1), with numerous being up-regulated (e.g. several transmembrane proteins) and others down-regulated (e.g. Aquaporin-5 and sulfate transporter) as presented in Fig. 4 and Supplementary Table S2. This indicates that the exposure to

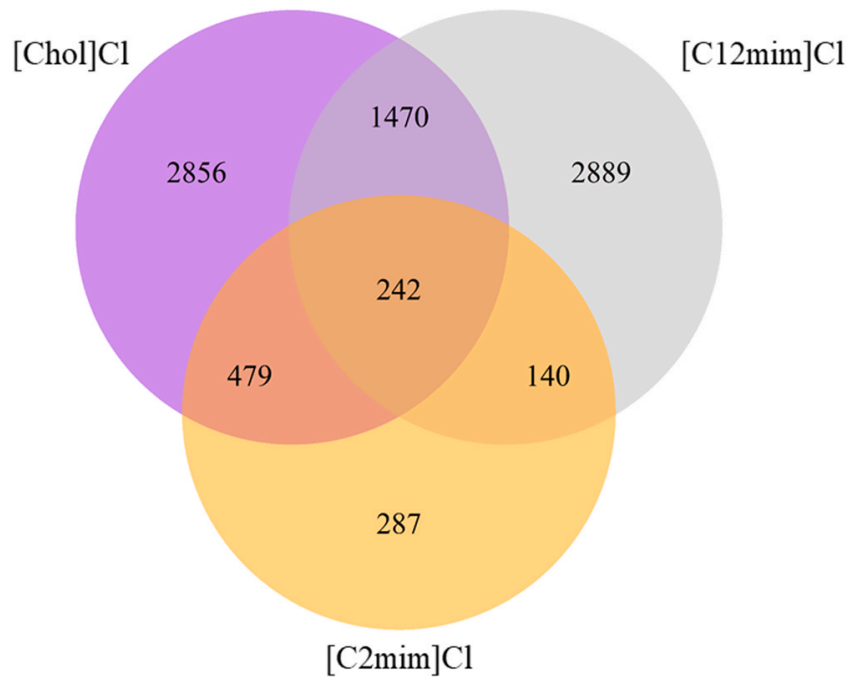

Fig. 2. Venn Diagram overlapping the number of genes significantly (GLM; FDR level of 0.05) differentially expressed from the control following exposure to $[\mathrm{Chol}] \mathrm{Cl},\left[\mathrm{C}_{2} \mathrm{mim}\right] \mathrm{Cl}$ and $\left[\mathrm{C}_{12} \mathrm{mim}\right] \mathrm{Cl}$. 


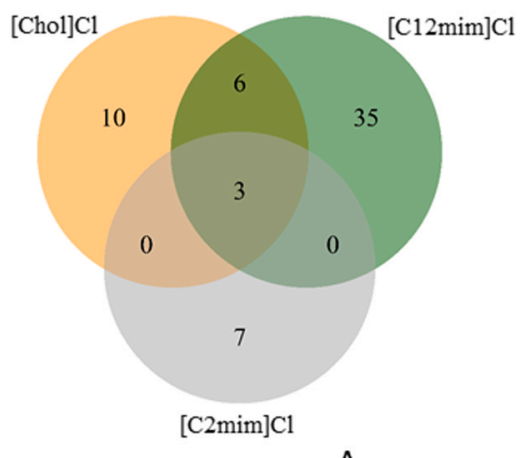

A

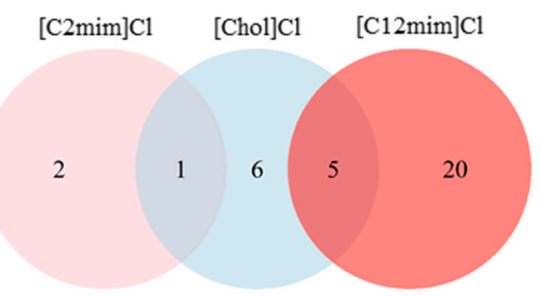

B

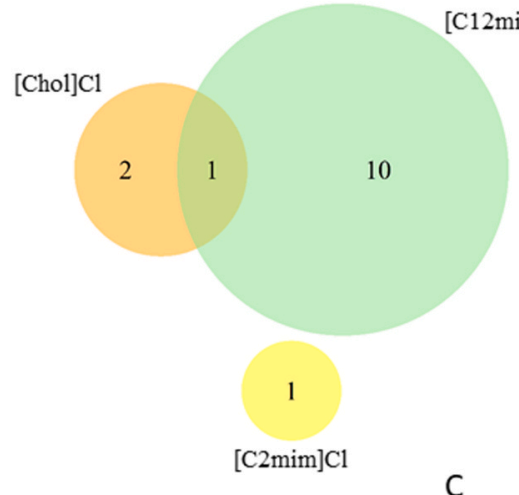

C

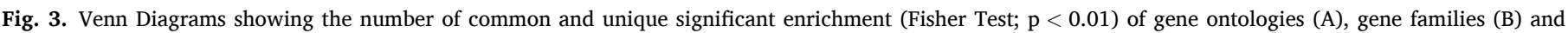
pathways (C) relatively to the control following exposure of $D$. magna to $[\mathrm{Chol}] \mathrm{Cl},\left[\mathrm{C}_{2} \mathrm{mim}\right] \mathrm{Cl}$ and $\left[\mathrm{C}_{12} \mathrm{mim}\right] \mathrm{Cl}$.

the ILs likely provoked major changes in the cell membrane of Daphnia (Venkata Nancharaiah et al., 2012; Yoo et al., 2016; Xia et al., 2018), compromising the integrity of cells. The structural integrity of the cell seems further to be impacted by ILs, as denoted by numerous changes in the expression of cytoskeleton-related genes, including the up-regulation of Actin-related protein 2/3 complex subunit gene and down-regulation of genes and factors coding for the depolymerization of filaments (Supplementary Table S1) as well as the significant enrichment (Table 2) of related gene ontologies (e.g. Actin cytoskeleton organization) and families (e.g. Prefoldin subunit), which may signal the establishment of higher level effects. Supporting this view, the Focal adhesion pathway was significantly enriched following exposure to $\left[\mathrm{C}_{12} \mathrm{mim}\right] \mathrm{Cl}$ and [Chol] Cl (Fig. 3; Table 2), which serves as a mechanical and signaling connection between the actin cytoskeleton and membrane receptors; changes in this pathway have been correlated with cancer and developmental abnormalities (Lang et al., 2006; Korsnes et al., 2007). Therefore, our results agree with previous claims that ILs can modify the rigidity and morphology of the cells, by acting on the physical properties of the outer cell layer, which is linked to the actin cytoskeleton (Galluzzi et al., 2018). Consistently, differential expression and significant enrichment was observed for important molecular features - e.g. gene neurexin IV (Supplementary Table S1), gene ontology Myosin complex and metabolic pathways Adherens junction and ECM-receptor interaction (Table 2) - whose biological functions include cell signaling and adhesion, e.g. cell-cell contact and cell-matrix adhesion (Stork et al., 2009).

The formation of reactive oxygen species (ROS) is known to be a general trigger of ILs toxicity, eventually towards cell membrane damage and cell integrity breakdown (Kumar et al., 2011; Wu et al., 2013; Du et al., 2014). Increased ROS production together with the inhibition (rather than increased activity) of antioxidant enzymes has been observed consistently as a result of exposure of different aquatic organisms to ILs (Yu et al., 2009; Dong et al., 2013). We found evidence that the down-regulation of genes encoding for components of these enzymes also occurs at the transcriptional level (Supplementary Table S1), reinforcing that the antioxidant system of Daphnia is ineffective in protecting cells from oxidative stress promoted by ILs (Yu et al., 2009; Dong et al., 2013) as these compounds do not only cause ROS increase but also directly affect the antioxidant defense of the cells. Increased ROS production is also linked with impacts in several cellular structures, e.g. mitochondria, endoplasmic reticulum and nucleus, as well as impacts in different pathways, including detoxification and lipids metabolism (Chen et al., 2018; Zeis et al., 2019). Accordingly, we found significant differential expression of the gene glutathione S-transferase Mu 3 (Supplementary Table S1) following exposure to all tested ILs. Given that the mu class of glutathione S-transferase enzymes is involved in the detoxification of xenobiotics linked with the antioxidant defense activity (Liu et al., 2020), our results suggest the involvement of detoxification mechanisms for coping with IL exposure. Nevertheless, the up-regulation of the gene was observed in the $\left[\mathrm{C}_{12} \mathrm{mim}\right] \mathrm{Cl}$ treatment while its down-regulation was conversely found for both the least toxic ILs ([ $\left.\mathrm{C}_{2} \mathrm{mim}\right] \mathrm{Cl}$ and [Chol] Cl) (Supplementary Table S2; Fig. 4).

Major changes in gene expression occurred regarding mitochondrial metabolism, including the differential expression of the Acyl coa dehydrogenase gene, encoding for a mitochondrial enzyme that is involved in the breakdown of fatty acid molecules through the $\beta$-oxidation pathway, which has been touted to be a key route in the biodegradation of ILs (Ghisla and Thorpe, 2004; Jordan and Gathergood, 2015). Also for Acyl coa dehydrogenase, a positive fold change in the expression was observed following exposure to $\left[\mathrm{C}_{12} \mathrm{mim}\right] \mathrm{Cl}$ while $\left[\mathrm{C}_{2} \mathrm{mim}\right] \mathrm{Cl}$ and $[\mathrm{Chol}] \mathrm{Cl}$ treatments resulted in the down-regulation of the gene (Supplementary Table S2; Fig. 4). Moreover, differential gene expression shared by the three tested ILs occurred on other mitochondrial genes (e.g. L-2-hydroxyglutarate dehydrogenase, mitochondrial and mitochondrial atp synthase $b$ chain), possibly resulting in alterations in mitochondrial morphology, membrane polarization and ATP synthesis inhibition (Scammells et al., 2005; Li et al., 2012; Dickinson et al., 2016). Significant enrichment was observed of e.g. gene ontology Oxidoreductase activity and metabolic pathway ATP synthase (Table 2) supporting the occurrence of higher-level consequences as a result of related gene expression changes. The overall down-regulation of the mitochondrial gene coding for 4-aminobutyrate aminotransferase was also observed (Supplementary Table S1). Similar results were reported by Martins et al. (2013), who found major changes in metabolic processes in two fungi due to exposure to $[\mathrm{Chol}] \mathrm{Cl}$ and $\left[\mathrm{C}_{2} \mathrm{mim}\right] \mathrm{Cl}$. Consistently, we found a down-regulation of the gene coding for lipase (Supplementary Table S1), the enzyme catalyzing lipid hydrolysis (Hasler, 1935). Again, specific regulation analysis denotes that $\left[\mathrm{C}_{12} \mathrm{mim}\right] \mathrm{Cl}$ promoted the up-regulation of these genes, while $\left[\mathrm{C}_{2} \mathrm{mim}\right] \mathrm{Cl}$ and $[\mathrm{Chol}] \mathrm{Cl}$ promoted their down-regulation (Fig. 4; Supplementary Table S2).

Protein biosynthesis seems to be another target of ILs in general, as suggested by the differential expression found for genes encoding $40 \mathrm{~S}$ and 605 proteins and mitochondrial ribosomal proteins (Supplementary Table S1). In Daphnia, differential regulation of ribosomes has been previously reported as a general effect of several stressors, including metals, cyanobacterial species and carbamates, at the transcriptional level (Pereira et al., 2010; Vandegehuchte et al., 2010; Asselman et al., 2012). Consistently, specific energy allocation for the purpose of increased protein synthesis was already observed following stressor insult (Asselman et al., 2012). In addition, several genes involved on crustacean molt cycles were down-regulated, namely genes implicated in cuticle construction, collagen formation, chitin processes and carbonate dehydratase activity. This suggests that daphnids are increasing the length of their instars and decelerating molting cycles to save energy as a strategy to cope with $\mathrm{IL}$ exposure. Both [Chol] $\mathrm{Cl}$ and $\left[\mathrm{C}_{12} \mathrm{mim}\right] \mathrm{Cl}$ promoted the significant enrichment of gene ontologies and families related to cuticle and collagen (Table 2), supporting the likelihood of 
Table 2

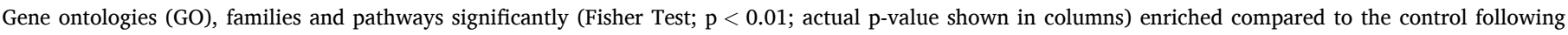
exposure to each tested IL. Annotations retrieving uninformative or unspecific terms (e.g. uncharacterized proteins) were excluded from this dataset summary.

\begin{tabular}{|c|c|c|c|}
\hline Gene ontology & {$\left[\mathrm{C}_{2} \mathrm{mim}\right] \mathrm{Cl}$} & {$[\mathrm{Chol}] \mathrm{Cl}$} & {$\left[\mathrm{C}_{12} \mathrm{mim}\right] \mathrm{Cl}$} \\
\hline \multicolumn{4}{|l|}{ Shared patterns of enrichment } \\
\hline Carbohydrate metabolic process & & $7.18 \times 10^{-2 *}$ & $8.52 \times 10^{-5}$ \\
\hline Hydrolase activity, hydrolyzing O-glycosyl compound & & $3.16 \times 10^{-1 *}$ & $7.51 \times 10^{-4 *}$ \\
\hline Proteolysis & $9.86 \times 10^{-4}$ & $3.21 \times 10^{-4}$ & $8.21 \times 10^{-7 *}$ \\
\hline Protein kinase activity & & $5.31 \times 10^{-4 *}$ & $7.15 \times 10^{-10}$ \\
\hline Protein phosphorylation & & $7.44 \times 10^{-4 *}$ & $9.08 \times 10^{-10}$ \\
\hline Protein tyrosine kinase activity & & $7.44 \times 10^{-4 *}$ & $2.80 \times 10^{-10}$ \\
\hline Serine-type endopeptidase activity & $1.06 \times 10^{-4}$ & $7.44 \times 10^{-4}$ & $2.28 \times 10^{-4 *}$ \\
\hline Structural constituent of cuticle & & $2.45 \times 10^{-27}$ & $2.94 \times 10^{-32}$ \\
\hline tRNA aminoacylation for protein translation & $9.35 \times 10^{-3 *}$ & $3.16 \times 10^{-1 *}$ & $3.94 \times 10^{-3 *}$ \\
\hline \multicolumn{4}{|l|}{ Unique enrichment signatures } \\
\hline Actin cytoskeleton organization & $3.54 \times 10^{-3}$ & & \\
\hline \multicolumn{3}{|l|}{ Aminoacyl-tRNA ligase activity* } & $6.69 \times 10^{-3}$ \\
\hline \multicolumn{2}{|l|}{ ATP binding* } & $4.34 \times 10^{-5}$ & \\
\hline \multicolumn{2}{|l|}{ Carboxypeptidase activity* } & & $3.36 \times 10^{-6}$ \\
\hline \multicolumn{2}{|l|}{ Catalytic activity } & & $2.43 \times 10^{-3 *}$ \\
\hline \multicolumn{2}{|l|}{ Cation binding* } & & $9.70 \times 10^{-4}$ \\
\hline \multicolumn{2}{|l|}{ Chitin binding } & $1.10 \times 10^{-4}$ & \\
\hline \multicolumn{2}{|l|}{ Chitin metabolic process } & $1.28 \times 10^{-4}$ & \\
\hline Chromosome organization & $3.54 \times 10^{-3}$ & & \\
\hline \multicolumn{3}{|l|}{ Collagen trimer* } & $3.36 \times 10^{-4}$ \\
\hline Endopeptidase activity & & & $2.84 \times 10^{-3}$ \\
\hline Extracellular matrix structural constituent* & & & $3.36 \times 10^{-4}$ \\
\hline Extracellular region & & $2.03 \times 10^{-3}$ & \\
\hline Fucosyltransferase activity* & & & $4.20 \times 10^{-3}$ \\
\hline Galactosyltransferase activity* & & & $4.50 \times 10^{-3}$ \\
\hline Immune response & $3.54 \times 10^{-3}$ & & \\
\hline Integral component of membrane ${ }^{*}$ & & & $1.29 \times 10^{-5}$ \\
\hline Kinase activity* & & $4.49 \times 10^{-2}$ & \\
\hline Lipid metabolic process & & $2.65 \times 10^{-1}$ & \\
\hline Metabolic process* & & & $4.00 \times 10^{-5}$ \\
\hline Metal ion binding & & & $3.32 \times 10^{-3}$ \\
\hline Metallocarboxypeptidase activity* & & & $3.80 \times 10^{-5}$ \\
\hline Metallopeptidase activity* & & & $4.20 \times 10^{-3}$ \\
\hline Methyltransferase activity* & & & $6.55 \times 10^{-3}$ \\
\hline Microtubule motor activity* & & $5.02 \times 10^{-2}$ & \\
\hline Microtubule-based movement* & & $5.02 \times 10^{-2}$ & \\
\hline Motor activity & & & $8.23 \times 10^{-3}$ \\
\hline Myosin complex & & & $8.23 \times 10^{-3}$ \\
\hline NAD (P)+-protein-arginine ADP-ribosyltransferase activity & $3.68 \times 10^{-4}$ & & \\
\hline Nucleotide binding & $2.89 \times 10^{-3}$ & & \\
\hline Oxidoreductase activity & & $6.54 \times 10^{-2}$ & \\
\hline Proteasome core complex & & & $8.03 \times 10^{-6}$ \\
\hline Proteasome core complex, alpha-subunit complex & & & $2.84 \times 10^{-3}$ \\
\hline Protein ADP-ribosylation & $1.09 \times 10^{-3}$ & & \\
\hline Protein binding & & & $3.72 \times 10^{-10}$ \\
\hline Protein glycosylation* & & & $8.04 \times 10^{-6}$ \\
\hline Protein import & & & $6.28 \times 10^{-3}$ \\
\hline Protein ubiquitination & & & $8.04 \times 10^{-3}$ \\
\hline Proteolysis involved in cellular protein catabolic process & & & $8.03 \times 10^{-6}$ \\
\hline Regulation of Rho protein signal transduction & & & $2.49 \times 10^{-5}$ \\
\hline Rho guanyl-nucleotide exchange factor activity & & & $2.49 \times 10^{-5}$ \\
\hline Rho GTPase binding & $3.54 \times 10^{-3}$ & & \\
\hline Ribosome & & & $1.04 \times 10^{-13}$ \\
\hline Structural constituent of ribosome & & & $2.12 \times 10^{-13}$ \\
\hline Threonine-type endopeptidase activity & & & $8.03 \times 10^{-6}$ \\
\hline Transferase activity, transferring acyl groups* & & $1.34 \times 10^{-1}$ & \\
\hline Transferase activity, transferring glycosyl groups & & & $4.48 \times 10^{-3}$ \\
\hline Transferase activity, transferring hexosyl groups* & & & $2.00 \times 10^{-4}$ \\
\hline Translation & & & $2.59 \times 10^{-12}$ \\
\hline Transmembrane transport* & & & $1.64 \times 10^{-3}$ \\
\hline Transmembrane transporter activity* & & & $1.50 \times 10^{-4}$ \\
\hline Ubiquitin-protein transferase activity & & & $5.80 \times 10^{-6}$ \\
\hline Gene family & {$\left[\mathrm{C}_{2} \mathrm{mim}\right] \mathrm{Cl}$} & {$[\mathrm{Chol}] \mathrm{Cl}$} & {$\left[\mathrm{C}_{12} \mathrm{mim}\right] \mathrm{Cl}$} \\
\hline Shared patterns of enrichment & & & \\
\hline Collagen & & $1.18 \times 10^{-5}$ & $8.38 \times 10^{-3}$ \\
\hline Cuticle protein & & $1.25 \times 10^{-31}$ & $1.35 \times 10^{-31}$ \\
\hline NADH dehydrogenase & & $7.45 \times 10^{-4 *}$ & $2.81 \times 10^{-3}$ \\
\hline Pollen-specific leucine-rich repeat extensin protein 1 & & $2.14 \times 10^{-3}$ & $8.21 \times 10^{-4}$ \\
\hline Serine Protease & & $4.23 \times 10^{-4}$ & $9.20 \times 10^{-3 *}$ \\
\hline Unique enrichment signatures & & & \\
\hline 39 S ribosomal protein, mitochondrial & & & $3.64 \times 10^{-6}$ \\
\hline $40 \mathrm{~S}$ ribosomal protein & & & $1.15 \times 10^{-12}$ \\
\hline & & & d on next page) \\
\hline
\end{tabular}




\begin{tabular}{|c|c|c|c|}
\hline Gene family & {$\left[\mathrm{C}_{2} \mathrm{mim}\right] \mathrm{Cl}$} & {$[\mathrm{Chol}] \mathrm{Cl}$} & {$\left[\mathrm{C}_{12} \mathrm{mim}\right] \mathrm{Cl}$} \\
\hline $60 \mathrm{~S}$ ribosomal protein & & & $8.46 \times 10^{-11}$ \\
\hline ATP synthase & & & $6.89 \times 10^{-4}$ \\
\hline Bromodomain-containing protein & & & $2.70 \times 10^{-3}$ \\
\hline Calcium/calmodulin-dependent protein kinase & & & $4.48 \times 10^{-3}$ \\
\hline Carboxyl/cholinesterase & & $4.15 \times 10^{-4}$ & \\
\hline Carboxypeptidase & & & $1.42 \times 10^{-4 *}$ \\
\hline Chitin_bind_4, Insect cuticle protein & & $8.87 \times 10^{-4}$ & \\
\hline Chorion peroxidase & & $6.36 \times 10^{-3}$ & \\
\hline c-type lectin & & & $4.22 \times 10^{-3 *}$ \\
\hline Endoglucanase & $7.96 \times 10^{-3}$ & & \\
\hline Eukaryotic translation initiation factor & & & $1.63 \times 10^{-3}$ \\
\hline Kinesin protein & & $8.21 \times 10^{-3}$ & \\
\hline Lactosylceramide & & & $6.26 \times 10^{-3 *}$ \\
\hline Luciferin 4-monooxygenase & & & $3.36 \times 10^{-3 *}$ \\
\hline Neurexin IV & & & $4.22 \times 10^{-3 *}$ \\
\hline Prefoldin subunit & & & $6.25 \times 10^{-3}$ \\
\hline Pro-resilin & & & $4.48 \times 10^{-3}$ \\
\hline Pro-resilin & & & $6.25 \times 10^{-3}$ \\
\hline Proteasome subunit alpha type & & & $8.21 \times 10^{-4}$ \\
\hline Pupal cuticle protein & & $2.14 \times 10^{-3}$ & \\
\hline Ras-related protein & & & $1.37 \times 10^{-3 *}$ \\
\hline Serine threonine-protein kinase & & & $1.88 \times 10^{-3}$ \\
\hline Signal peptide peptidase & & $2.14 \times 10^{-3}$ & \\
\hline Soluble guanylate cyclase $89 \mathrm{Da}$ & & & $4.48 \times 10^{-3}$ \\
\hline Structural maintenance of chromosomes protein & $7.96 \times 10^{-3}$ & & \\
\hline Transmembrane emp24 domain-containing protein & & & $6.25 \times 10^{-3}$ \\
\hline Gene pathway & {$\left[\mathrm{C}_{2} \mathrm{mim}\right] \mathrm{Cl}$} & {$[\mathrm{Chol}] \mathrm{Cl}$} & {$\left[\mathrm{C}_{12} \mathrm{mim}\right] \mathrm{Cl}$} \\
\hline \multicolumn{4}{|l|}{ Shared patterns of enrichment } \\
\hline Focal adhesion & & $1.67 \times 10^{-4}$ & $2.16 \times 10^{-4}$ \\
\hline \multicolumn{4}{|l|}{ Unique enrichment signatures } \\
\hline Adherens junction & & & $8.37 \times 10^{-3}$ \\
\hline Alzheimer's disease & & & $1.47 \times 10^{-6}$ \\
\hline Aminoacyl-tRNA biosynthesis & $1.12 \times 10^{-3}$ & & \\
\hline ECM-receptor interaction & & $7.73 \times 10^{-11}$ & \\
\hline ErbB signaling pathway & & & $2.31 \times 10^{-3}$ \\
\hline GnRH signaling pathway & & & $5.41 \times 10^{-4}$ \\
\hline Long-term potentiation & & & $1.26 \times 10^{-3}$ \\
\hline Nitrogen metabolism & & $9.41 \times 10^{-5}$ & \\
\hline Oxidative phosphorylation & & & $1.33 \times 10^{-3}$ \\
\hline Proteasome & & & $1.33 \times 10^{-6}$ \\
\hline Regulation of actin cytoskeleton & & & $5.84 \times 10^{-3}$ \\
\hline Ribosome & & & $5.11 \times 10^{-23}$ \\
\hline Tight junction & & & $3.53 \times 10^{-3}$ \\
\hline
\end{tabular}

\footnotetext{
* Significant enrichment effects are under-represented as the ratio between significant and non-significant genes is lower than the equivalent ratio for the whole set
} of differentially expressed genes.

higher level effects regarding the molting cycle and consequently growth. It is worth noting that collagens have also important functions for the structural integrity of tissues, and the disturbance of collagen genes can trigger a wide spectrum of diseases (Myllyharju and Kivirikko, 2001).

The repair of DNA and RNA seems to have been triggered by exposure to all ILs (e.g. up-regulation of the gene Alpha-ketoglutarate-dependent dioxygenase alkB; Supplementary Table S1), which may be a response to ROS insult or to direct impact as ILs can enter the cell nucleus and directly damage the DNA (Li et al., 2012; Dong et al., 2013; Jumbri et al., 2020). Programmed cell death occurring as a response to the three ILs is suggested by the overall up-regulation of apoptosis-related genes (Momeni, 2011), e.g. Calpain and mitogen-activated protein kinase (Supplementary Table S1), possibly as a downstream result of combined cell membrane and mitochondrial damage deriving from the unsuccessful management of oxidative stress (Ranke et al., 2006; Martins et al., 2013). Moreover, the role of epigenetic mechanisms in regulating the highlighted differential gene expression patterns was apparent, as suggested by the up-regulation of genes involved in DNA methylation and histone modifications (Supplementary Table S1). In fact, epigenetic mechanisms have been shown to have a central role in the response of Daphnia to stressors (e.g. Jeremias et al. 2018), thus further studies should be carried out to clarify the involvement of epigenetic processes in the response of Daphnia to ILs exposure.

\subsection{Unique gene expression signatures of ILs: specific mechanisms of toxic action}

Despite there is this set of 242 genes becoming differentially expressed following exposure to all tested ILs (see above), in a large part opposite regulation trends were observed among the ILs (Supplementary Table S2; Fig. 4). This opposite regulation is particularly evident between $\left[\mathrm{C}_{12} \mathrm{mim}\right] \mathrm{Cl}$ and [Chol] $\mathrm{Cl}$ (Fig. 4), denoting different effects of the two cations on gene expression. On the one hand, this reflects the lower potential of $\left[\mathrm{C}_{2} \mathrm{mim}\right] \mathrm{Cl}$ to induce transcriptional changes in Daphnia; on the other hand, IL-specific gene expression regulation is a preliminary support for the existence of IL-specific mechanisms of toxic action, and possibly allows the identification of unique signatures of toxicity at the molecular level.

Regarding $\left[\mathrm{C}_{2} \mathrm{mim}\right] \mathrm{Cl}$, we found 287 genes uniquely differentially expressed from the control as well as the enrichment of the Endoglucanase and Structural maintenance of chromosomes (SMC) gene families (Table 2; Figs. 2 and 3). The Endoglucanase family of genes is involved in gluconeogenesis, which is an important mechanism of energy production to Daphnia (Nagato et al., 2016) and the SMC family clusters genes involved in the repair of double-stranded breaks in DNA and maintenance of ribosomal DNA stability. The importance of the SMC family to the stress-response of Daphnia is becoming increasingly recognized (Gómez et al., 2016; Hearn et al., 2018), and our results suggest that 


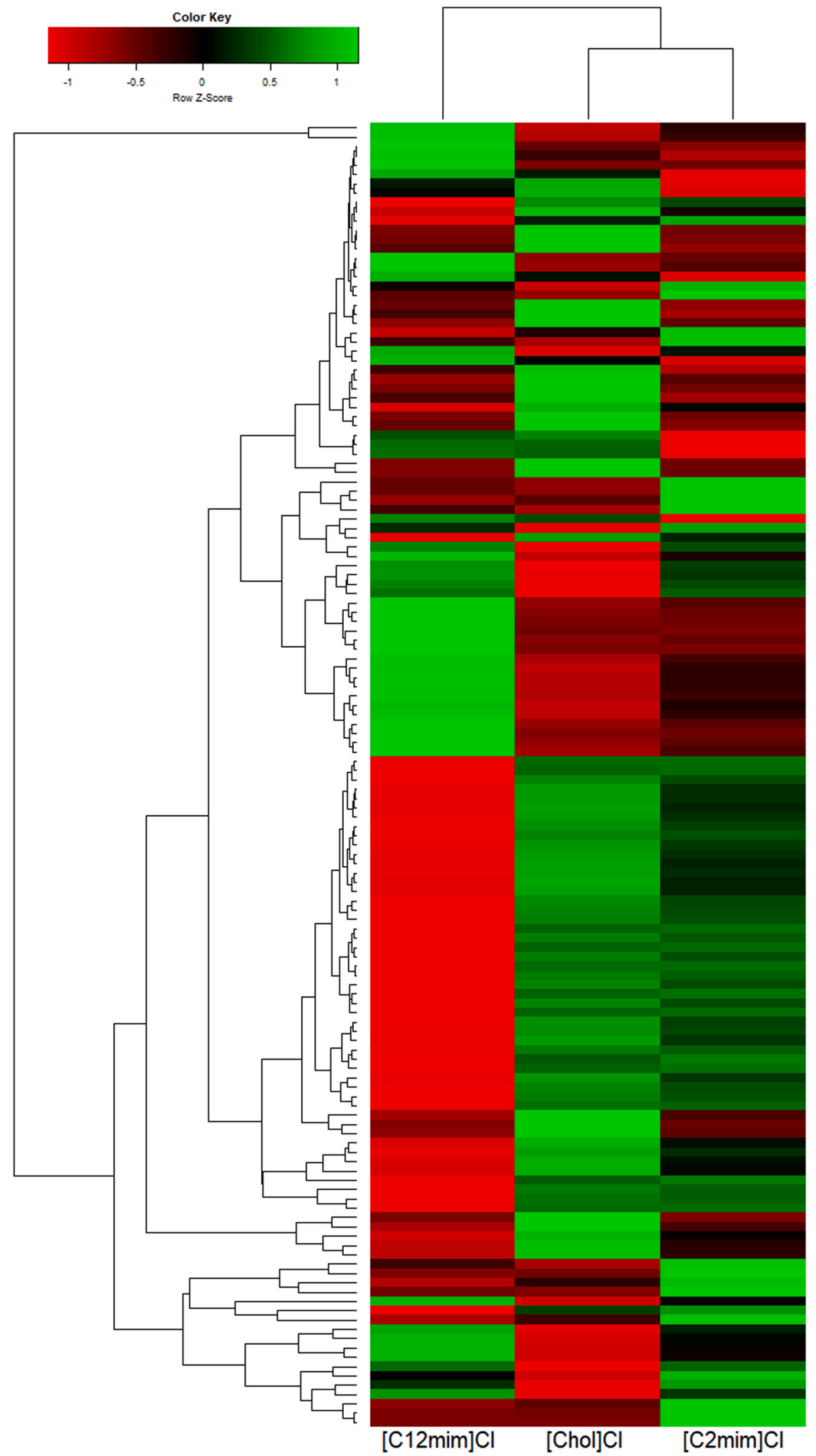

Fig. 4. Heatmap for the fold changes of genes differentially expressed shared by the [Chol] $\mathrm{Cl}$, [C2mim]Cl and [C12mim] $\mathrm{Cl}$ treatments. Gene- and treatment- specific fold change values are detailed in Supplementary Table S2. 
DNA damage and genomic instability should be important mechanisms of toxicity of $\left[\mathrm{C}_{2} \mathrm{mim}\right] \mathrm{Cl}$ towards Daphnia. In addition, the expression of several genes related to disease initiation and immune response (e.g. Metastasis suppressor protein and Suppressor of cytokine signaling 1) (Mansell et al., 2006) changed due to $\left[\mathrm{C}_{2} \mathrm{mim}\right] \mathrm{Cl}$ exposure, although the same was observed in the [Chol] $\mathrm{Cl}$ treatment. These specific effects of $\left[\mathrm{C}_{2} \mathrm{mim}\right] \mathrm{Cl}$ in gene expression suggest that, despite this IL was the least toxic at the transcriptional level, it may induce higher-level physiological changes in Daphnia.

Specific effects of exposure to [Chol]Cl included 2856 genes exclusively differentially expressed from the control (Fig. 2), as well as the unique significant enrichment of 10 gene ontologies, 6 gene families and 2 pathways (Nitrogen metabolism, ECM-receptor interaction) (Table 2; Fig. 3). Consistently, and as per the chemical structure of the cholinium cation, the Carboxyl/cholinesterase family and several related genes were found uniquely overrepresented and largely down-regulated (Table 2), respectively, which relates to the involvement of the encoded proteins in the metabolic process of choline and related compounds (Wu and Hoy, 2016). Previous studies reported that [Chol] $\mathrm{Cl}$ exposure provoked changes in the amino acid metabolism of a fungus species (Aspergillus nidulans) as a result of changes occurring in carbon and nitrogen sources (Alves et al., 2016). Accordingly, the Nitrogen metabolism pathway was found uniquely enriched following exposure to [Chol] $\mathrm{Cl}$ (Table 2), due to the involvement of choline as a constituent of lipids and the neurotransmitter acetylcholine in Daphnia (Jordão et al., 2015; Gómez-Canela et al., 2019). This view is reinforced by the overrepresentation of genes regulating the metabolism of lipids (uniquely enriched gene ontologies: Lipid metabolic process and Transferase activity, the latter under-represented considering the whole dataset; Table 2). Moreover, the Extracellular matrix (ECM)-receptor interaction pathway, which was found uniquely enriched as a response to [Chol]Cl (Table 2), controls important cellular activities such as adhesion, migration, differentiation, proliferation, apoptosis and also plays an important role in tissue function and organ morphogenesis (Gkretsi and Stylianopoulos, 2018). Remarkably, changes in this pathway were demonstrated to occur due to oxidant-antioxidant disturbances (among other stressing scenarios) in the zebrafish, ultimately impairing embryogenesis (Zhang et al., 2017; Zou et al., 2020). Finally, it is worth noting the unique enrichment of the Chorion peroxidase gene family promoted by [Chol] Cl (Table 2). As such genes seem to be important in reproduction, especially in the chorion formation and hardening, this may indicate an early impairment of D. magna reproduction due to [Chol] $\mathrm{Cl}$ exposure (Yang et al., 2017). Note that exposure was run during the first instars and way before the onset of egg development.

The exposure to $\left[\mathrm{C}_{12} \mathrm{mim}\right] \mathrm{Cl}$ resulted in 2889 genes uniquely deferentially expressed and determined the enrichment of 33 gene ontologies, 3 families and 10 pathways (Table 2; Figs. 2 and 3). The molecular and biological functions of these unique genes and enriched features support that $\left[\mathrm{C}_{12} \mathrm{mim}\right] \mathrm{Cl}$ can extensively affect the cell membrane and cytoskeleton (e.g. down-regulation of Cytoskeleton-associated protein gene and enrichment of the Regulation of actin cytoskeleton pathway; Supplementary Table S3 and Table 2), likely resulting in changes in cell morphology, motility and function, ultimately causing cell death and disease development (Bhat et al., 2019). In particular, the enrichment of Tight and Adherens junctions pathways evidenced the ability of $\left[\mathrm{C}_{12} \mathrm{mim}\right] \mathrm{Cl}$ to interfere with cell proliferation, differentiation and migration, as well as affecting cell-cell contacts (Hartsock and Nelson, 2008; Yang et al., 2014). Changes in both pathways have been related to the development of diseases (Hartsock and Nelson, 2008; Bhat et al., 2019). Furthermore, the exposure to $\left[\mathrm{C}_{12} \mathrm{mim}\right] \mathrm{Cl}$ promoted changes (unique in some cases) in the expression of numerous ribosomal genes, as well as the enrichment of Ribosomal and Proteasome pathways (Table 2), suggesting the impairment of protein synthesis and degradation, as well as of essential cellular functions, e.g. cell cycle, cell differentiation or signal transduction (Myung et al., 2001). Such changes are energy demanding, and we consistently observed the overrepresentation of the Oxidative phosphorylation pathway (Table 2). Although this scenario is consistent with increased energy production or with the negative effects of ROS in the mitochondria (Dickinson et al., 2016), both understood as general responses to stress, these pathways were not found overrepresented neither following exposure to $\left[\mathrm{C}_{2} \mathrm{mim}\right]$ $\mathrm{Cl}$ nor to [Chol]Cl. Al last, the $\left[\mathrm{C}_{12} \mathrm{mim}\right] \mathrm{Cl}$-specific effects in gene expression suggest impairment of cell functioning and signaling processes, as well as of the development and function of the nervous system. For instance, the four pathways exclusively enriched following exposure to $\left[\mathrm{C}_{12} \mathrm{mim}\right] \mathrm{Cl}$ (Table 2) included the Gonadotropin-releasing hormone signaling and $E r b B$ (or epidermal growth factor receptor) signaling pathways (see Supplementary Table S3 for the differentially expressed genes involved), both playing important roles in e.g. cell growth and survival; changes in these pathways have been linked with cell programmed death and disease initiation (Gondi et al., 2009; Wang et al., 2012). Finally, further studies should clarify on the effective occurrence of neurological disorders in Daphnia since the significant enrichment of the Long-term potentiation (LTP) and Alzheimer's disease (AD) was observed, as well as significant gene expression changes in numerous related genes as detailed in Supplementary Table S4, including the Serine/threonine-protein kinase mTOR and Amyloid beta A4 protein genes (Yoshimoto et al., 1995; Ma et al., 2010). Taking into account that Daphnia is becoming increasingly recognized as a valid model for the prospect of mammalian and, in particular, human health effects of exposure to chemicals (Siciliano and Gesuele, 2013; Rivetti et al., 2016), these findings are particularly concerning and raise awareness towards potentially severe toxic effects of $\left[\mathrm{C}_{12} \mathrm{mim}\right] \mathrm{Cl}$ that have been unnoticed so far.

\section{Conclusion}

The common mechanisms of toxicity shared by $\left[\mathrm{C}_{2} \mathrm{mim}\right] \mathrm{Cl}$, $[\mathrm{Chol}] \mathrm{Cl}$ and $\left[\mathrm{C}_{12} \mathrm{mim}\right] \mathrm{Cl}$ towards Daphnia magna included cellular membrane and cytoskeleton damage, oxidative stress, inhibition of antioxidant enzymes, mitochondrial impairment, changes in protein biosynthesis and energy production, and DNA damage. Ultimately, these effects should result in programmed cell death (apoptosis) and disease initiation. Despite the presence of common mechanisms, unique gene expression signatures were recognized for each of the three ILs. While the gene expression profiles corresponding to samples exposed to $\left[\mathrm{C}_{2} \mathrm{mim}\right] \mathrm{Cl}$ and control were found similar, the exposure to $\left[\mathrm{C}_{12} \mathrm{mim}\right] \mathrm{Cl}$ affected gene expression more pronouncedly than $\left[\mathrm{C}_{2} \mathrm{mim}\right] \mathrm{Cl}$, thereby highlighting the effect of the alkyl chain as an important driver of ILs toxicity. On the other hand, higher relative impacts at the molecular level were found driven by $[\mathrm{Chol}] \mathrm{Cl}$ compared to $\left[\mathrm{C}_{2} \mathrm{mim}\right] \mathrm{Cl}$. The distinctive gene expression patterns of $[\mathrm{Chol}] \mathrm{Cl}$ and $\left[\mathrm{C}_{2} \mathrm{mim}\right] \mathrm{Cl}$ emphasizes that imidazolium- and cholinium-based ILs can be distinguished by some typical mechanisms of toxicity. In accordance to the general expression patterns, enrichment analysis reinforced the following relative toxicity ordering at the transcriptional level: $\left[\mathrm{C}_{2} \mathrm{mim}\right]$ $\mathrm{Cl}<[\mathrm{Chol}] \mathrm{Cl} \ll\left[\mathrm{C}_{12} \mathrm{mim}\right] \mathrm{Cl}$. This supports the view that $\left[\mathrm{C}_{2} \mathrm{mim}\right] \mathrm{Cl}$ bears the lowest potential to induce transcriptional changes in D. magna, as well as it confirms the inconsistency of the picture generally touting the cholinium family of ILs as environmentally safer than imidazoliumbased ILs. Unique signatures of each IL were highlighted since no consistent shared enrichment was found among the tested ILs. Overall, the alkyl chain ecotoxicological effect of ILs was confirmed but the postulated higher toxicity of the imidazolium cation compared to the cholinium cation was not confirmed regarding effects denoted at the gene expression level, thus suggesting that long-term toxicity studies and further comprehension of biodegradability are necessary to better frame the suitability of this heuristic rule to assist the prospective environmental risk assessment of ILs. The validation of these findings using other model species, in particular with species representing different trophic or functional levels, would also be an asset for the comprehensive understanding of the environmental hazardous potential 
of imidazolium- and cholinium-based ILs.

\section{CRediT authorship contribution statement}

Guilherme Jeremias: Investigation, Formal analysis, Writing original draft. Fátima Jesus: Investigation, Writing - original draft. Sónia Ventura: Conceptualization, Supervision, Writing - review \& editing. Fernando Gonçalves: Conceptualization, Supervision, Funding acquisition, Writing - review \& editing. Jana Asselman: Formal analysis, Writing - review \& editing. Joana Pereira: Conceptualization, Formal analysis, Supervision, Writing - original draft, Writing - review \& editing.

\section{Declaration of Competing Interest}

The authors declare that they have no known competing financial interests or personal relationships that could have appeared to influence the work reported in this paper.

\section{Acknowledgements}

Thanks are due to FCT/MCTES for the financial support to CESAM (UIDP/50017/2020+UIDB/50017/2020) and CICECO (UIDB/50011/ 2020 \& UIDP/50011/2020), through national funds. This work was supported by the project PTDC/ATP-EAM/5331/2014 funded by FCT. GJ is the recipient of an individual FCT (SFRH/BD/139076/2018) research grant. JLP is funded by national funds (OE), through FCT, I.P., in the scope of the framework contract foreseen in article 23 , of the Decree-Law 57/2016, changed by Law 57/2017.

\section{Appendix A. Supporting information}

Supplementary data associated with this article can be found in the online version at doi:10.1016/j.jhazmat.2020.124517.

\section{References}

Alves, P.C., Hartmann, D.O., Núñez, O., Martins, I., Gomes, T.L., Garcia, H., Galceran, M. T., Hampson, R., Becker, J.D., Pereira, C.S., 2016. Transcriptomic and metabolomic profiling of ionic liquid stimuli unveils enhanced secondary metabolism in Aspergillus nidulans. BMC Genom. 17, 284. https://doi.org/10.1186/s12864-0162577-6.

Amde, M., Liu, J.F., Pang, L., 2015. Environmental application, fate, effects, and concerns of ionic liquids: a review. Environ. Sci. Technol. 49, 12611-12627. https:// doi.org/10.1021/acs.est.5b03123.

Anders, S., Pyl, P.T., Huber, W., 2015. HTSeq-A Python framework to work with highthroughput sequencing data. Bioinformatics 31, 166-169. https://doi.org/10.1093/ bioinformatics/btu638.

Asselman, J., De Coninck, D.I.M., Glaholt, S., Colbourne, J.K., Janssen, C.R., Shaw, J.R., De Schamphelaere, K.A.C., 2012. Identification of pathways, gene networks, and paralogous gene families in Daphnia pulex responding to exposure to the toxic cyanobacterium Microcystis aeruginosa. Environ. Sci. Technol. 46, 8448-8457. https://doi.org/10.1021/es301100j.

ASTM, 1980. Standard Practice for Conducting Acute Toxicity Tests with Fishes, Macroinvertebrates and Amphibians. American Society for Testing and Materials, Philadelphia.

Baird, D., Soares, A., Girling, A., Barber, I., Bradley, M., Calow, P. The long-term maintenance of Daphnia magna Straus for use in ecotoxicity test: problems and prospects. In: Lokke, H., Tyle, H., Bro-Rasmussen, F. (Eds.), Proceedings First European Conference on Ecotoxicology, Lyngby, Denmark, 1989, pp. 144-148.

Bernot, R.J., Brueseke, M.A., Evans-White, M.A., Lamberti, G.A., 2005. Acute and chronic toxicity of imidazolium-based ionic liquids on Daphnia magna. Environ. Toxicol. Chem. 24, 87-92. https://doi.org/10.1897/03-635.1.

Bhat, A.A., Uppada, S., Achkar, I.W., Hashem, S., Yadav, S.K., Shanmugakonar, M., AlNaemi, H.A., Haris, M., Uddin, S., 2019. Tight junction proteins and signaling pathways in cancer and inflammation: a functional crosstalk. Front. Physiol. 9, 1942. https://doi.org/10.3389/fphys.2018.01942.

Bolger, A.M., Lohse, M., Usadel, B., 2014. Trimmomatic: a flexible trimmer for Illumina sequence data. Bioinformatics 30, 2114-2120.

Bubalo, M.C., Radošević, K., Redovniković, I.R., Slivac, I., Srček, V.G., 2017. Toxicity mechanisms of ionic liquids. Arch. Ind. Hyg. Toxicol. 68, 171-179. https://doi.org/ 10.1515/aiht-2017-68-2979.

Carpenter, S.R., Kitchell, J.F., Hodgson, J.R., 1985. Cascading trophic interactions and lake productivity. Bioscience 35, 634-639.
Chen, Z., Zhou, Q., Guan, W., Wang, J., Li, Y., Yu, N., Wei, J., 2018. Effects of imidazolium-based ionic liquids with different anions on wheat seedlings. Chemosphere 194, 20-27. https://doi.org/10.1016/j.chemosphere.2017.11.145.

Colbourne, J.K., Pfrender, M.E., Gilbert, D., Thomas, W.K., Tucker, A., Oakley, T.H., Tokishita, S., Aerts, A., Arnold, G.J., Basu, M.K., Bauer, D.J., Cáceres, C.E., Carmel, L., Choi, J., Detter, J.C., Dong, Q., Dusheyko, S., Eads, D., Fröhlich, T., Geiler-samerotte, K. a, Gerlach, D., Schaack, S., Shapiro, H., Shiga, Y., Skalitzky, C., 2011. The ecoresponsive genome of D. pulex. Science 331, 555-561. https://doi. org/10.1126/science.1197761. The.

De Coninck, D.I.M., Asselman, J., Glaholt, S., Janssen, C.R., Colbourne, J.K., Shaw, J.R., De Schamphelaere, K.A.C., 2014. Genome-wide transcription profiles reveal genotype-dependent responses of biological pathways and gene-families in daphnia exposed to single and mixed stressors. Environ. Sci. Technol. 48, 3513-3522. https://doi.org/10.1021/es4053363.

Cook, K., Tarnawsky, K., Swinton, A.J., Yang, D.D., Senetra, A.S., Caputo, G.A., Carone, B.R., Vaden, T.D., 2019. Correlating lipid membrane permeabilities of imidazolium ionic liquids with their cytotoxicities on yeast, bacterial, and mammalian cells. Biomolecules 9, 251. https://doi.org/10.3390/biom9060251.

Costa, S.P.F., Azevedo, A.M.O., Pinto, P.C.A.G., Saraiva, M.L.M.F.S., 2017. Environmental impact of ionic liquids: recent advances in (eco)toxicology and (bio) degradability. ChemSusChem 10, 2321-2347. https://doi.org/10.1002/ cssc. 201700261.

Cvjetko Bubalo, M., Radošević, K., Radojčić Redovniković, I., Halambek, J., Gaurina Srček, V., 2014. A brief overview of the potential environmental hazards of ionic liquids. Ecotoxicol. Environ. Saf. 99, 1-12. https://doi.org/10.1016/j. ecoenv 2013.10.019.

Dickinson, Q., Bottoms, S., Hinchman, L., McIlwain, S., Li, S., Myers, C.L., Boone, C., Coon, J.J., Hebert, A., Sato, T.K., Landick, R., Piotrowski, J.S., 2016. Mechanism of imidazolium ionic liquids toxicity in Saccharomyces cerevisiae and rational engineering of a tolerant, xylose-fermenting strain. Microb. Cell Fact. 15, 17. https://doi.org/10.1186/s12934-016-0417-7.

Dobin, A., Davis, C.A., Schlesinger, F., Drenkow, J., Zaleski, C., Jha, S., Batut, P., Chaisson, M., Gingeras, T.R., 2013. STAR: ultrafast universal RNA-seq aligner Bioinformatics 29, 15-21.

Dong, M., Zhu, L., Zhu, S., Wang, J., Wang, J., Xie, H., Du, Z., 2013. Toxic effects of 1decyl-3-methylimidazolium bromide ionic liquid on the antioxidant enzyme system and DNA in zebrafish (Danio rerio) livers. Chemosphere 91, 1107-1112. https://doi. org/10.1016/j.chemosphere.2013.01.013.

Du, Z., Zhu, L., Dong, M., Wang, J., Wang, J., Xie, H., Liu, T., Guo, Y., 2014. Oxidative stress and genotoxicity of the ionic liquid 1-Octyl-3- methylimidazolium bromide in zebrafish (Danio rerio). Arch. Environ. Contam. Toxicol. 67, 261-269. https://doi. org/10.1007/s00244-014-0046-2.

Egorova, K.S., Gordeev, E.G., Ananikov, V.P., 2017. Biological activity of ionic liquids and their application in pharmaceutics and medicine. Chem. Rev. 117, 7132-7189. https://doi.org/10.1021/acs.chemrev.6b00562.

Galluzzi, M., Schulte, C., Milani, P., Podestà, A., 2018. Imidazolium-based ionic liquids affect morphology and rigidity of living cells: an atomic force microscopy study. Langmuir 34, 12452-12462. https://doi.org/10.1021/acs.langmuir.8b01554.

Garcia, H., Ferreira, R., Petkovic, M., Ferguson, J.L., Leitão, M.C., Gunaratne, H.Q.N., Seddon, K.R., Rebelo, L.P.N., Silva Pereira, C., 2010. Dissolution of cork biopolymers in biocompatible ionic liquids. Green Chem. 12, 367-369. https://doi.org/10.1039/ b922553f.

Ghisla, S., Thorpe, C., 2004. Acyl-CoA dehydrogenases: a mechanistic overview. Eur. J. Biochem. 271, 494-508. https://doi.org/10.1046/j.1432-1033.2003.03946.x.

Gkretsi, V., Stylianopoulos, T., 2018. Cell adhesion and matrix stiffness: coordinating cancer cell invasion and metastasis. Front. Oncol. 8, 145. https://doi.org/10.3389/ fonc. 2018.00145 .

Gómez-Canela, C., Rovira García, X., Martínez-Jerónimo, F., Marcé, R.M., Barata, C., 2019. Analysis of neurotransmitters in Daphnia magna affected by neuroactive pharmaceuticals using liquid chromatography-high resolution mass spectrometry. Environ. Pollut. 254, 113029 https://doi.org/10.1016/j.envpol.2019.113029.

Gómez, R., Van Damme, K., Gosálvez, J., Morán, E.S., Colbourne, J.K., 2016. Male meiosis in Crustacea: synapsis, recombination, epigenetics and fertility in Daphnia magna. Chromosoma 125, 769-787. https://doi.org/10.1007/s00412-015-0558-1.

Gondi, C.S., Dinh, D.H., Klopfenstein, J.D., Gujrati, M., Rao, J.S., 2009. MMP-2 downregulation mediates differential regulation of cell death via ErbB-2 in glioma xenografts. Int. J. Oncol. 35, 257-263.

Hall, D.J., Threlkeld, S.T., Burns, C.W., Crowley, P.H., 1976. The size-efficiency hypothesis and the size structure of zooplankton communities. Annu. Rev. Ecol. Syst. 7, 177-208.

Han, Y., Gao, S., Muegge, K., Zhang, W., Zhou, B., 2015. Advanced applications of RNA sequencing and challenges. Bioinform. Biol. Insights 9s1, 29-46. https://doi.org/ 10.4137/BBI.S28991.

Hartmann, D.O., Shimizu, K., Siopa, F., Leitão, M.C., Afonso, C.A.M., Canongia Lopes, J. N., Silva Pereira, C., 2015. Plasma membrane permeabilisation by ionic liquids: a matter of charge. Green Chem. 17, 4587-4598. https://doi.org/10.1039/ c5gc01472g.

Hartsock, A., Nelson, W.J., 2008. Adherens and tight junctions: structure, function and connections to the actin cytoskeleton. Biochim. Biophys. Acta Biomembr. 1778 , 660-669. https://doi.org/10.1016/j.bbamem.2007.07.012.

Hasler, A.D., 1935. The physiology of digestion of plankton crustacea: I. Some digestive enzymes of daphnia. Biol. Bull. 68, 207-214.

Hearn, J., Pearson, M., Blaxter, M., Wilson, P.J., Little, T.J., 2018. Genome-wide methylation patterns under caloric restriction in Daphnia magna. BioRxiv, 278408. https://doi.org/10.1101/278408. 
Heckenbach, M.E., Romero, F.N., Green, M.D., Halden, R.U., 2016. Meta-analysis of ionic liquid literature and toxicology. Chemosphere 150, 266-274. https://doi.org/ 10.1016/j.chemosphere.2016.02.029.

Jeremias, G., Barbosa, J., Marques, S.M., De Schamphelaere, K.A.C., Van Nieuwerburgh, F., Deforce, D., Gonçalves, F.J.M., Pereira, J.L., Asselman, J., 2018. Transgenerational inheritance of DNA hypomethylation in Daphnia magna in response to salinity stress. Environ. Sci. Technol. 52, 10114-10123. https://doi.org/ 10.1021/acs.est.8b03225.

Jordan, A., Gathergood, N., 2015. Biodegradation of ionic liquids-a critical review. Chem. Soc. Rev. 44, 8200-8237. https://doi.org/10.1039/C5CS00444F.

Jordão, R., Casas, J., Fabrias, G., Campos, B., Piña, B., Lemos, M.F.L., Soares, A.M.V.M., Tauler, R., Barata, C., 2015. Obesogens beyond vertebrates: lipid perturbation by tributyltin in the crustacean Daphnia magna. Environ. Health Perspect. 123, 813-819. https://doi.org/10.1289/ehp.1409163.

Jumbri, K., Kassim, M.A., Yunus, N.M., Abdul Rahman, M.B., Ahmad, H., Wahab, R.A., 2020. Fluorescence and molecular simulation studies on the interaction between imidazolium-based ionic liquids and calf thymus. Processes 8, 13. https://doi.org/ 10.3390/pr8010013.

Khudyakov, J.I., D'Haeseleer, P., Borglin, S.E., DeAngelis, K.M., Woo, H., Lindquist, E.A. Hazen, T.C., Simmons, B.A., Thelen, M.P., 2012. Global transcriptome response to ionic liquid by a tropical rain forest soil bacterium, Enterobacter lignolyticus. Proc. Natl. Acad. Sci. USA 109, E2173-E2182. https://doi.org/10.1073/ pnas.1112750109.

Korsnes, M.S., Hetland, D.L., Espenes, A., Aune, T., 2007. Cleavage of tensin during cytoskeleton disruption in YTX-induced apoptosis. Toxicol. Vitr. 21, 9-15. https:// doi.org/10.1016/j.tiv.2006.07.012.

Kubisa, P., 2004. Application of ionic liquids as solvents for polymerization processes. Prog. Polym. Sci. 29, 3-12. https://doi.org/10.1016/j.progpolymsci.2003.10.002.

Kumar, M., Trivedi, N., Reddy, C.R.K., Jha, B., 2011. Toxic effects of imidazolium ionic liquids on the green seaweed Ulva lactuca: oxidative stress and DNA damage. Chem. Res. Toxicol. 24, 1882-1890. https://doi.org/10.1021/tx200228c.

Lampert, W., 2006. Daphnia: model herbivore, predator and prey. Pol. J. Ecol. 54, $607-620$

Lang, M.R., Lapierre, L.A., Frotscher, M., Goldenring, J.R., Knapik, E.W., 2006. Secretory COPII coat component Sec23a is essential for craniofacial chondrocyte maturation. Nat. Genet. 38, 1198-1203.

Liu, Z., Jiao, Y., Chen, Q., Li, Y., Tian, J., Huang, Y., Cai, M., Wu, D., Zhao, Y., 2020. Two sigma and two mu class genes of glutathione S-transferase in the waterflea Daphnia pulex: molecular characterization and transcriptional response to nanoplastic exposure. Chemosphere 248, 126065. https://doi.org/10.1016/j. chemosphere.2020.126065.

Liu, J., Yang, G., Liu, Y., Wu, D., Hu, X., Zhang, Z., 2019. Metal-free imidazolium hydrogen carbonate ionic liquids as bifunctional catalysts for the one-pot synthesis of cyclic carbonates from olefins and $\mathrm{CO}_{2}$. Green Chem. 21, 3834-3838. https://doi. org/10.1039/c9gc01088b.

Liu, H., Zhang, X., Chen, C., Du, S., Dong, Y., 2015. Effects of imidazolium chloride ionic liquids and their toxicity to Scenedesmus obliquus. Ecotoxicol. Environ. Saf. 122, 83-90. https://doi.org/10.1016/j.ecoenv.2015.07.010.

Li, X.Y., Jing, C.Q., Lei, W.L., Li, J., Wang, J.J., 2012. Apoptosis caused by imidazoliumbased ionic liquids in PC12 cells. Ecotoxicol. Environ. Saf. 83, 102-107. https://doi. org/10.1016/j.ecoenv.2012.06.013.

Macário, I.P.E., Veloso, T., Pereira, J.L., Ventura, S.P.M., Coutinho, J.A.P., 2020 Potential threats of ionic liquids to the environment and ecosphere. In: Zhang, S (Ed.), Encyclopedia of Ionic Liquids. Springer, Singapore. https://doi.org/10.1007/ 978-981-10-6739-6 66-1.

Mansell, A., Smith, R., Doyle, S.L., Gray, P., Fenner, J.E., Crack, P.J., Nicholson, S.E., Hilton, D.J., O'Neill, L.A.J., Hertzog, P.J., 2006. Suppressor of cytokine signaling 1 negatively regulates Toll-like receptor signaling by mediating Mal degradation. Nat. Immunol. 7, 148-155. https://doi.org/10.1038/ni1299.

Martins, I., Hartmann, D.O., Alves, P.C., Planchon, S., Renaut, J., Leitão, M.C., Rebelo, L P.N., Silva Pereira, C., 2013. Proteomic alterations induced by ionic liquids in Aspergillus nidulans and Neurospora crassa. J. Proteom. 94, 262-278. https://doi org/10.1016/j.jprot.2013.09.015

Matzke, M., Arning, J., Ranke, J., Jastorff, B., Stolte, S., 2013. Design of inherently safer ionic liquids: toxicology and biodegradation. In: Anastas, P.T., Wasserscheid, P., Stark, A. (Eds.), Green Solvents: Ionic Liquids. Wiley, p. 365.

Ma, T., Hoeffer, C.A., Capetillo-Zarate, E., Yu, F., Wong, H., Lin, M.T., Tampellini, D., Klann, E., Blitzer, R.D., Gouras, G.K., 2010. Dysregulation of the mTOR pathway mediates impairment of synaptic plasticity in a mouse model of Alzheimer's disease. PLoS One 5, e12845. https://doi.org/10.1371/journal.pone.0012845.

Mena, I.F., Diaz, E., Palomar, J., Rodriguez, J.J., Mohedano, A.F., 2020. Cation and anion effect on the biodegradability and toxicity of imidazolium- and choline-based ionic liquids. Chemosphere 240, 124947. https://doi.org/10.1016/j. chemosphere.2019.124947.

Mendonca, C.M.N., Balogh, D.T., Barbosa, S.C., Sintra, T.E., Ventura, S.P.M., Martins, L. F.G., Morgado, P., Filipe, E.J.M., Coutinho, J.A.P., Oliveira, O.N., BarrosTimmons, A., 2018. Understanding the interactions of imidazolium-based ionic liquids with cell membrane models. Phys. Chem. Chem. Phys. 20, 29764-29777. https://doi.org/10.1039/c8cp05035j.

Miner, B.E., De Meester, L., Pfrender, M.E., Lampert, W., Hairston, N.G., 2012. Linking genes to communities and ecosystems: Daphnia as an ecogenomic model. Proc. R. Soc. B Biol. Sci. 279, 1873-1882. https://doi.org/10.1098/rspb.2011.2404.

Momeni, H.R., 2011. Role of calpain in apoptosis. Cell J. 13, 65-72.

Munoz, M., Domínguez, C.M., De Pedro, Z.M., Quintanilla, A., Casas, J.A., Ventura, S.P. M., Coutinho, J.A.P., 2015. Role of the chemical structure of ionic liquids in their ecotoxicity and reactivity towards Fenton oxidation. Sep. Purif. Technol. 150, 252-256. https://doi.org/10.1016/j.seppur.2015.07.014.

Myllyharju, J., Kivirikko, K.I., 2001. Collagens and collagen-related diseases. Ann. Med. 33, 7-21. https://doi.org/10.3109/07853890109002055.

Myung, J., Kim, K.B., Crews, C.M., 2001. The ubiquitin-proteasome pathway and proteasome inhibitors. Med. Res. Rev. 21, 245-273. https://doi.org/10.1002/ med.1009.

Nagato, E.G., Simpson, A.J., Simpson, M.J., 2016. Metabolomics reveals energetic impairments in Daphnia magna exposed to diazinon, malathion and bisphenol-A. Aquat. Toxicol. 170, 175-186. https://doi.org/10.1016/j.aquatox.2015.11.023. , 2004OECD, 2004. OECD guideline for testing of chemica is 202 - Daphnia sp., acute immobilisation test, Paris.

Orsini, L., Gilbert, D., Podicheti, R., Jansen, M., Brown, J.B., Solari, O.S., Spanier, K.I. Colbourne, J.K., Rush, D., Decaestecker, E., Asselman, J., De Schamphelaere, K.A.C., Ebert, D., Haag, C.R., Kvist, J., Laforsch, C., Petrusek, A., Beckerman, A.P., Little, T. J., Chaturvedi, A., Pfrender, M.E., De Meester, L., Frilander, M.J., 2016. Daphnia magna transcriptome by RNA-Seq across 12 environmental stressors. Sci. Data 3, 160030. https://doi.org/10.1038/sdata.2016.30.

Ozsolak, F., Milos, P.M., 2011. RNA sequencing: advances, challenges and opportunities. Nat. Rev. Genet. 12, 87-98.

Parajó, J.J., Macário, I.P.E., De Gaetano, Y., Dupont, L., Salgado, J., Pereira, J.L., Gonçalves, F.J.M., Mohamadou, A., Ventura, S.P.M., 2019. Glycine-betaine-derived ionic liquids: synthesis, characterization and ecotoxicological evaluation. Ecotoxicol. Environ. Saf. 184, 109580 https://doi.org/10.1016/j.ecoenv.2019.109580.

Pawłowska, B., Telesiński, A., Biczak, R., 2019. Phytotoxicity of ionic liquids. Chemosphere 237, 124436. https://doi.org/10.1016/j.chemosphere.2019.124436.

Pereira, J.L., Hill, C.J., Sibly, R.M., Bolshakov, V.N., Gonçalves, F., Heckmann, L.H., Callaghan, A., 2010. Gene transcription in Daphnia magna: effects of acute exposure to a carbamate insecticide and an acetanilide herbicide. Aquat. Toxicol. 97, 268-276. https://doi.org/10.1016/j.aquatox.2009.12.023.

Petkovic, M., Ferguson, J., Bohn, A., Trindade, J., Martins, I., Carvalho, M.B., Leitão, M. C., Rodrigues, C., Garcia, H., Ferreira, R., Seddon, K.R., Rebelo, L.P.N., Silva Pereira, C., 2009. Exploring fungal activity in the presence of ionic liquids. Green Chem. 11, 889. https://doi.org/10.1039/b823225c.

Piña, B., Casado, M., Quirós, L., 2007. Analysis of gene expression as a new tool in ecotoxicology and environmental monitoring. TrAC Trends Anal. Chem. 26, 1145-1154. https://doi.org/10.1016/j.trac.2007.09.009.

Plechkova, N.V., Seddon, K.R., 2008. Applications of ionic liquids in the chemical industry. Chem. Soc. Rev. 37, 123-150. https://doi.org/10.1039/b006677j.

Ranke, J., Cox, M., Müller, A., Schmidt, C., Beyersmann, D., 2006. Sorption, cellular distribution, and cytotoxicity of imidazolium ionic liquids in mammalian cells influence of lipophilicity. Toxicol. Environ. Chem. 88, 273-285. https://doi.org/ 10.1080/02772240600589505.

Rivetti, C., Campos, B., Barata, C., 2016. Low environmental levels of neuro-active pharmaceuticals alter phototactic behaviour and reproduction in Daphnia magna. Aquat. Toxicol. 170, 289-296. https://doi.org/10.1016/j.aquatox.2015.07.019.

Robinson, M.D., Oshlack, A., 2010. A scaling normalization method for differential expression analysis of RNA-seq data. Genome Biol. 11, R25. https://doi.org/ 10.1186/gb-2010-11-3-r25.

Romero, A., Santos, A., Tojo, J., Rodríguez, A., 2008. Toxicity and biodegradability of imidazolium ionic liquids. J. Hazard. Mater. 151, 268-273. https://doi.org/ 10.1016/j.jhazmat.2007.10.079.

Santos, J.I., Gonçalves, A.M.M., Pereira, J.L., Figueiredo, B.F.H.T., Silva, F.A.E., Coutinho, J.A.P., Ventura, S.P.M., Gonçalves, F., 2015. Environmental safety of cholinium-based ionic liquids: assessing structure-ecotoxicity relationships. Green Chem. 17, 4657-4668. https://doi.org/10.1039/c5gc01129a.

Santos, A.G., Ribeiro, B.D., Alviano, D.S., Coelho, M.A.Z., 2014. Toxicity of ionic liquids toward microorganisms interesting to the food industry. RSC Adv. 4, 37157-37163.

Scammells, P.J., Scott, J.L., Singer, R.D., 2005. Ionic liquids: the neglected issues. Aust. J. Chem. 58, 155-169. https://doi.org/10.1071/CH04272.

Shamshina, J.L., Rogers, R.D., 2020. Are ionic liquids enabling technology? Startup to scale-up to find out. In: Shiflett, M. (Ed.), Commercial Applications of Ionic Liquids. Springer, pp. 69-85.

Sharma, V.K., Mukhopadhyay, R., 2018. Deciphering interactions of ionic liquids with biomembrane. Biophys. Rev. 10, 721-734. https://doi.org/10.1007/s12551-0180410-y.

Siciliano, A., Gesuele, R., 2013. How Daphnia (Cladocera) assays may be used as bioindicators of health effects? J. Biodivers. Endanger. Species 01. https://doi.org/ 10.4172/2332-2543.s1-005.

Sintra, T.E., Nasirpour, M., Siopa, F., Rosatella, A.A., Gonçalves, F., Coutinho, J.A.P., Afonso, C.A.M., Ventura, S.P.M., 2017. Ecotoxicological evaluation of magnetic ionic liquids. Ecotoxicol. Environ. Saf. 143, 315-321. https://doi.org/10.1016/j. ecoenv.2017.05.034.

Stein, J.R., 1973. In: Handbook of Phycological Methods-Culture Methods and Growth Measurements. Cambridge University Press, Cambridge.

Stork, T., Thomas, S., Rodrigues, F., Silies, M., Naffin, E., Wenderdel, S., Klämbt, C. 2009. Drosophila Neurexin IV stabilizes neuron-glia interactions at the CNS midline by binding to Wrapper. Development 136, 1251-1261.

Subramanian, A., Tamayo, P., Mootha, V.K., Mukherjee, S., Ebert, B.L., Gillette, M.A. Paulovich, A., Pomeroy, S.L., Golub, T.R., Lander, E.S., Mesirov, J.P., 2005. Gene set enrichment analysis: a knowledge-based approach for interpreting genome-wide expression profiles. Proc. Natl. Acad. Sci. USA 102, 15545-15550. https://doi.org/ 10.1073 pnas.0506580102.

R.C. Team, 2019. R: a language and environment for statistical computing. R Foundation for Statistical Computing, Vienna, Austria. 〈www.R-project.org/〉. 
Thuy Pham, T.P., Cho, C.W., Yun, Y.S., 2010. Environmental fate and toxicity of ionic liquids: a review. Water Res. 44, 352-372. https://doi.org/10.1016/j. watres.2009.09.030.

Vandegehuchte, M.B., Vandenbrouck, T., De Coninck, D., De Coen, W.M., Janssen, C.R., 2010. Gene transcription and higher-level effects of multigenerational $\mathrm{Zn}$ exposure in Daphnia magna. Chemosphere 80, 1014-1020. https://doi.org/10.1016/j. chemosphere.2010.05.032.

Venkata Nancharaiah, Y., Reddy, G.K.K., Lalithamanasa, P., Venugopalan, V.P., 2012. The ionic liquid 1-alkyl-3-methylimidazolium demonstrates comparable antimicrobial and antibiofilm behavior to a cationic surfactant. Biofouling 28, 1141-1149. https://doi.org/10.1080/08927014.2012.736966.

Ventura, S.P.M., Gonçalves, A.M.M., Sintra, T., Pereira, J.L., Gonçalves, F., Coutinho, J. A.P., 2013. Designing ionic liquids: the chemical structure role in the toxicity. Ecotoxicology 22, 1-12. https://doi.org/10.1007/s10646-012-0997-x.

Ventura, S.P.M., Silva, F.A. e, Gonçalves, A.M.M., Pereira, J.L., Gonçalves, F., Coutinho, J.A.P., 2014. Ecotoxicity analysis of cholinium-based ionic liquids to Vibrio fischeri marine bacteria. Ecotoxicol. Environ. Saf. 102, 48-54. https://doi. org/10.1016/j.ecoenv.2014.01.003.

Ventura, S.P.M., Silva, F.A.E., Quental, M.V., Mondal, D., Freire, M.G., Coutinho, J.A.P., 2017. Ionic-liquid-mediated extraction and separation processes for bioactive compounds: past, present, and future trends. Chem. Rev. 117, 6984-7052. https:// doi.org/10.1021/acs.chemrev.6b00550.

Wang, L., Chadwick, W., Park, S.-S., Zhou, Y., Silver, N., Martin, B., Maudsley, S., 2012. Gonadotropin-releasing hormone receptor system: modulatory role in aging and neurodegeneration. CNS Neurol. Disord. Drug Targets 9, 651-660. https://doi.org/ 10.2174/187152710793361559.

Wells, A.S., Coombe, V.T., 2006. On the freshwater ecotoxicity and biodegradation properties of some common ionic liquids. Org. Process Res. Dev. 10, 794-798. https://doi.org/10.1021/op060048i.

Wu, K., Hoy, M.A., 2016. The glutathione-S-transferase, cytochrome P450 and carboxyl/ cholinesterase gene superfamilies in predatory mite metaseiulus occidentalis. PLOS One 11, e0160009. https://doi.org/10.1371/journal.pone.0160009.

Wu, X., Tong, Z.H., Li, L.L., Yu, H.Q., 2013. Toxic effects of imidazolium-based ionic liquids on Caenorhabditis elegans: the role of reactive oxygen species. Chemosphere 93, 2399-2404. https://doi.org/10.1016/j.chemosphere.2013.08.040.

Xia, Y., Liu, D., Dong, Y., Chen, J., Liu, H., 2018. Effect of ionic liquids with different cations and anions on photosystem and cell structure of Scenedesmus obliquus. Chemosphere 195, 437-447. https://doi.org/10.1016/j.chemosphere.2017.12.054.
Yang, J.H., Kim, H.J., Lee, S.M., Kim, B.M., Seo, Y.R., 2017. Cadmium-induced biomarkers discovery and comparative network analysis in Daphnia magna. Mol. Cell. Toxicol. 13, 327-336. https://doi.org/10.1007/s13273-017-0036-3.

Yang, D., Lü, X., Hong, Y., Xi, T., Zhang, D., 2014. The molecular mechanism for effects of TiN coating on NiTi alloy on endothelial cell function. Biomaterials 35, 6195-6205. https://doi.org/10.1016/j.biomaterials.2014.04.069.

Yoo, B., Jing, B., Jones, S.E., Lamberti, G.A., Zhu, Y., Shah, J.K., Maginn, E.J., 2016. Molecular mechanisms of ionic liquid cytotoxicity probed by an integrated experimental and computational approach. Sci. Rep. 6, 19889. https://doi.org/ 10.1038/srep19889.

Yoshimoto, M., Iwai, A., Kang, D., Otero, D.A., Xia, Y., Saitoh, T., 1995. NACP, the precursor protein of the non-amyloid beta/A4 protein (A beta) component of Alzheimer disease amyloid, binds A beta and stimulates A beta aggregation. Proc. Natl. Acad. Sci. USA 92, 9141-9145. https://doi.org/10.1146/annurev-neuro061010-113613.

Yu, M., Wang, S.H., Luo, Y.R., Han, Y.W., Li, X.Y., Zhang, B.J., Wang, J.J., 2009. Effects of the 1-alkyl-3-methylimidazolium bromide ionic liquids on the antioxidant defense system of Daphnia magna. Ecotoxicol. Environ. Saf. 72, 1798-1804. https://doi.org/ 10.1016/j.ecoenv.2009.05.002.

Zeis, B., Buchen, I., Wacker, A., Martin-Creuzburg, D., 2019. Temperature-induced changes in body lipid composition affect vulnerability to oxidative stress in Daphnia magna. Comp. Biochem. Physiol. Part B Biochem. Mol. Biol. 232, 101-107. https:// doi.org/10.1016/j.cbpb.2019.03.008.

Zhang, J., Liu, L., Ren, L., Feng, W., Lv, P., Wu, W., Yan, Y., 2017. The single and joint toxicity effects of chlorpyrifos and beta-cypermethrin in zebrafish (Danio rerio) early life stages. J. Hazard. Mater. 334, 121-131. https://doi.org/10.1016/j. jhazmat.2017.03.055.

Zhang, C., Zhang, S., Zhu, L., Wang, J., Wang, J., Zhou, T., 2017. The acute toxic effects of 1-alkyl-3-methylimidazolium nitrate ionic liquids on Chlorella vulgaris and Daphnia magna. Environ. Pollut. 229, 887-895. https://doi.org/10.1016/j. envpol.2017.07.055.

Zhao, D., Liao, Y., Zhang, Z.D., 2007. Toxicity of ionic liquids. Clean 35, 42-48. https:// doi.org/10.1002/clen.200600015.

Zou, W., Zhang, X., Ouyang, S., Hu, X., Zhou, Q., 2020. Graphene oxide nanosheets mitigate the developmental toxicity of TDCIPP in zebrafish via activating the mitochondrial respiratory chain and energy metabolism. Sci. Total Environ. 727, 138486 https://doi.org/10.1016/j.scitotenv.2020.138486. 